\title{
The Vegetated Building Facades and their Contribution to Environmental Sustainability
}

\author{
Buddhi Chathuranjeli De Silva*, Nihal Perera, \\ Nandika Denipitiya \\ City school of architecture, Colombo, Sri Lanka \\ Corresponding Author: Buddhi Chathuranjeli De Silva; E-mail: buddhichathuranjelidesilva@gmail.com
}

\begin{abstract}
The number of people who are affected by urbanization has radically increased. However, the economic boom over the past decades has escalated the environmental problems. Among other solutions, environmentalists have proposed vertical greening, which refers to allowing vegetation to grow on the vertical surface of a building. With other sustainability-oriented strategies, vertical greening is thought to help resolve current environmental issues, as well as current health issues. It may prevent the cities from being unbearable during locked downs which impacts human's mental health due to social distancing measures. Green walls are an option for cities for people to engage with Nature. Known for their pleasantness to the senses and earthy qualities, they boost human health and improve air quality. Plants can thrive on walls, making it a popular trend globally and also welcomes antidotes to stress and isolation. Plants which contain day-to-day supply of nutrition and anti-germ characters, could be incorporated with green walls. However, more knowledge is needed to reap the potential benefits from it.

With the demand for sustainability, green walls are increasingly appearing on clients' requirement lists but mostly as a visual and aesthetic representation of sustainability. This sensibility of clients, what architects provide, and what is eventually built, questions whether the current vertical gardens deliver the intended benefits. Are these walls environmentally-friendly or are they just being a trend that takes advantage of the concern for the environment and human fondness to Nature?

In this research, certain measurements were used to assess the above gap. During the observation periods, for an example, number of utility bills were examined and thermometers were checked frequently. Structured interviews ascertained the people's perceptions. Research shows that there is a gap between what is actually proposed and what is practiced in Colombo in green walls. The study identified the gaps, such as the lack of adaptation to the local environment, proposed what each individual needs to improve to curtail the shortcomings.
\end{abstract}

Keywords: Environmental sustainability, vegetated facades, green walls, plant scraping, Colombo Sri Lanka

*Corresponding Author: Buddhi Chathuranjeli De Silva; E-mail- buddhichathuranjelidesilva@gmail.com 


\section{Introduction}

Today, majority of people live in urban areas. Urbanization attracts many people, which leads to congestion and create explicit issues such as pollution, and diseases and implicit impacts such as climate change. Moreover, residents and visitors may be in danger in the future if these issues escalate.

Should people want to live in non-infectious and risk-free environments, some solutions must be implemented to accommodate Nature in the cities. The best solution would be to use walls of buildings in these areas. Questions may rise how to integrate these buildings with greenery. Thus, architects spend so much time on experimenting and learning how these ideas work and grow sustainably. It is important not only for architects but also for clients, especially because the façade is what people see before visiting a building. Therefore, attention seeking investors implement various strategies to promote their buildings with green walls which are claimed to be eco-friendly and therefore popular.

Green walls could express the quality of the environments. They create positive energy and regenerate a person's immune system if they spend time near them. Some might wonder how to retain plants which are potential air purifiers, produce great scents... etc. It is already proven by modern science and it is no longer difficult to attach natural cleansers to walls.

Colombo has joined the trend of constructing vertical green walls too. Numerous studies on living wall have been published on this topic during the last five years. While these can aid, ideas change as they pass across societies. One of the questions this research aims to investigate is whether there is any gap between the current knowledge of green walls and what is practiced in Colombo?

\section{Theoretical Basis \\ Background of Vertical Gardening}

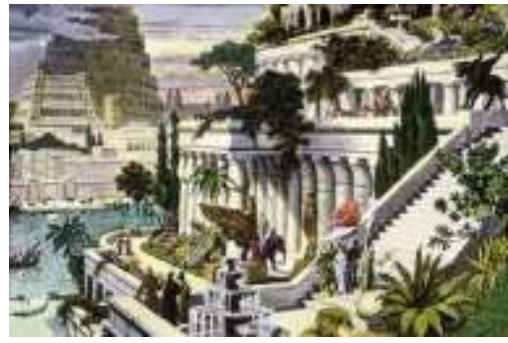

Fig. 1: Illustration of 'hanging gardens of Babylon'.

Source: Hand coloured engraving, Marten van Heemskerck, Dutch

In the Sri Lankan history, vertical gardens have been mentioned related to the pleasure gardens maintained for kings in Sigiriya and in the Giri monasteries. (Bopearachchi,2006)
Vertical gardening dates back to days as old as the Mesopotamian era (Petty, 2008). However, the earliest official record comes from Babylon as it had named their vertical gardens as 'hanging gardens of Babylon' (Petty, 2008). According to Petty, the Greeks shared a fair amount of vertical structures for agriculture (2008). In contrast, Romans used their gardens to better environments. Later, it was passed to the Persians (Bowe, 2004).

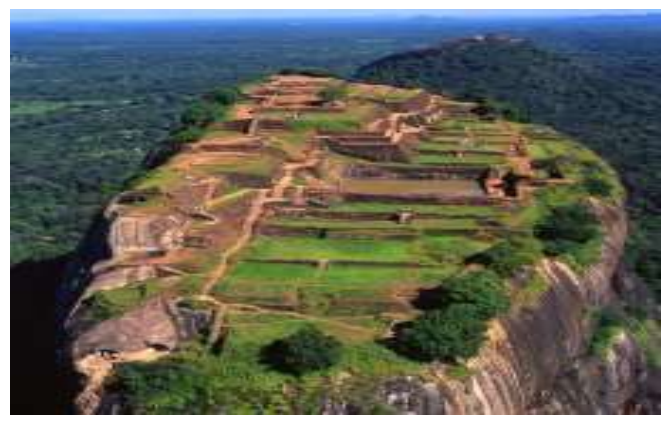

Fig. .2: Step Terraces of Sigiriya Source: Vladimir KovalSky 
Architect Hector Horeau was one of the first to take advantage of the novel materials of the time for his design for the Parisian boulevard by a light-weight and transparent glass structure that was designed incorporating draping flowering plants. They were installed in pots with soil and were given rainwater harvested from the roof according to the need of the plant. This system of hanging plants became popular and was some of the first examples of Modern vertical gardening methods (Leenhardt and Lambertini, 2007).

At end of the $19^{\text {th }}$ century, 'vertical gardening' was not only a part of a designers' vocabulary but part of botanists and landscape professionals' vocabulary too (Gothein,1966). The first contemporary example of vertical gardening came from a Brazilian landscape architect Roberto Burle Marx (Leenhardt and Lambertini, 2007). He worked on the theory related to plants that grow with little or no soil. This character can be brought to the urban context and as the concept was proven by Safra Bank building, Sao Paolo. At the beginning of the $20^{\text {th }}$ century, with the influence of the British, architects used climbers to cover the surfaces, especially in cottages and bungalows which could be seen in the Sri Lankan context as well.

General dissatisfaction with the prevailing architectural movement brought a counterculture which saw books like Design with Nature (1968) by Ian McHarg. The work of James Wines, Malcolm Wells, SITE, and others sought to integrate architecture with the principles of

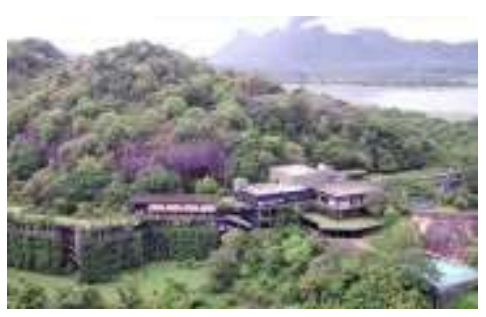

Fig. 3: Green wall at Kandalama hotel by Archt. Geoffrey Bawa Source: Sri Lanka Skyline

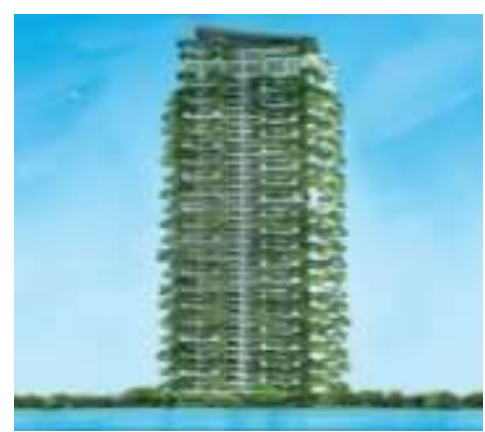
Ecological planning (Petty, 2008). As an attempt to create regional specific architecture, some believed regional plant species could be used in buildings to give a specific character. Architect Ken Yeang's Menara Mesiniaga Tower introduces vertical gardening to create a structure that responds to the character of its surrounding ecosystem.

The first contemporary formal use of vertical gardening in Sri Lanka is in the bungalows of the British Period. Kandalama Hotel designed by Architect Geoffrey Bawa is a notable example of the contemporary use of vertical gardening. Clear Point building, Rajagiriya by Archt. Milroy Perera is considered the modernday world's tallest vertical garden building in Colombo. Despite it is seen as a plant tower, it is constructed as garden terraces.

Fig. 5: Clear Point building, Rajagiriya by Archt. Milroy Perera Source: Sri Lanka skyline

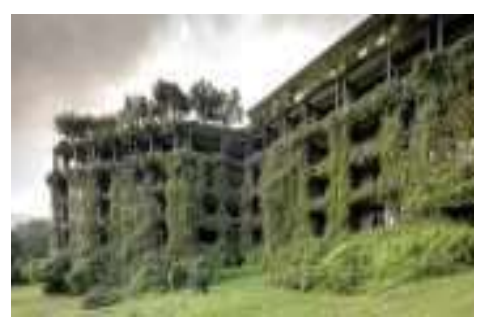

Fig. 4: Kandalama hotel by Geoffery Bawa Source: Sri Lanka Skyline 


\section{Green Walls and Vertical Gardening Vertical Gardening}

The term 'vertical garden' refers to any system of vertical planting that is attached to either the exterior or interior of a building and is self-sufficient in water and nutrients. These are also referred to as living walls or green walls. The plants receive water and nutrients from within the vertical support instead of from the ground (Tan, 2009). According to Peck (1999), the term 'vertical greenery' is used to define the growing of plants on, up, or against the façade of a building or feature walls. A green wall is essentially a living cladding system using climbing plants with many of the benefits of a green roof. Some have termed it an "organic wallpaper". "Vertical greenery" refers to having vegetation that grows directly onto a building's façade or to vegetation that is grown on a separate structural system that can be freestanding and adjacent or attached to the wall (Loh, 2008).

Modernism is believed to be the culprit behind the decline of green-clad architecture and the incorporation of Nature into a building (Petty, 2008).

The methods/strategies used can be broadly identified as follows.

Using the building façade as a vertical garden (surface)

> Using an additional structure attached to the building façade to act as a vertical garden (single skin)

Using an additional external planting structure detached from the external skin of the building (double skin)

Using horizontal planted terraces as layered vertical gardens on the building façade (layering

\section{Classification of Green Walls}

Exterior
Interior
Boundary Wall

Using the building façade as a vertical garden (surface)

$>$ Using an additional structure attached to the building façade to act as a vertical garden (single skin)

$>$ Using an additional external planting structure detached from the external skin of the building (double skin)

$>$ Using horizontally planted terraces as layered vertical gardens on the building façade (layering) 


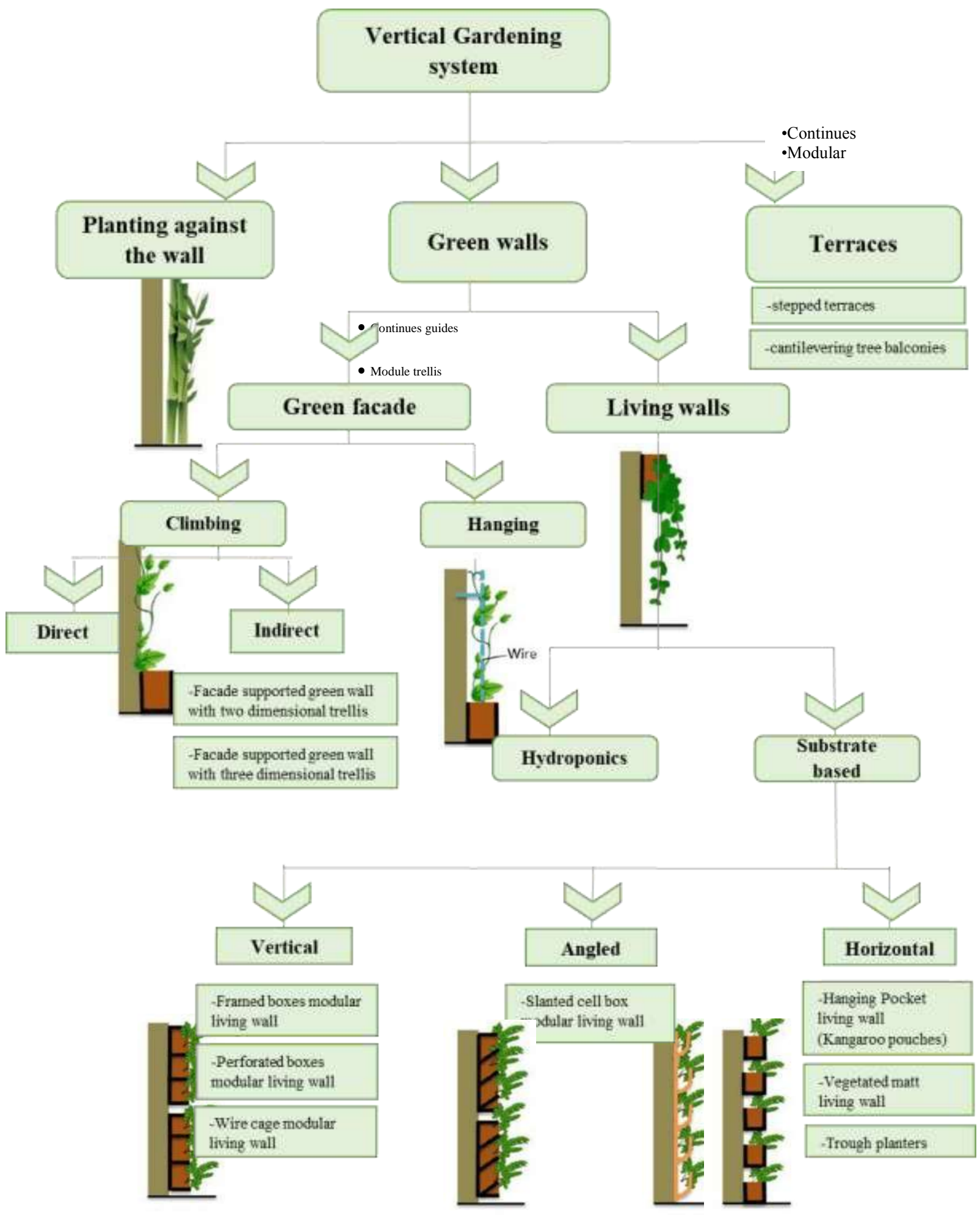

Fig. 6: Types of Vertical Gardening Systems

Source: by Author. Diagram based on the book: the Green walls in High-rise building (2014), Brković D, Marta,R Mina and Auer, T (2019) 

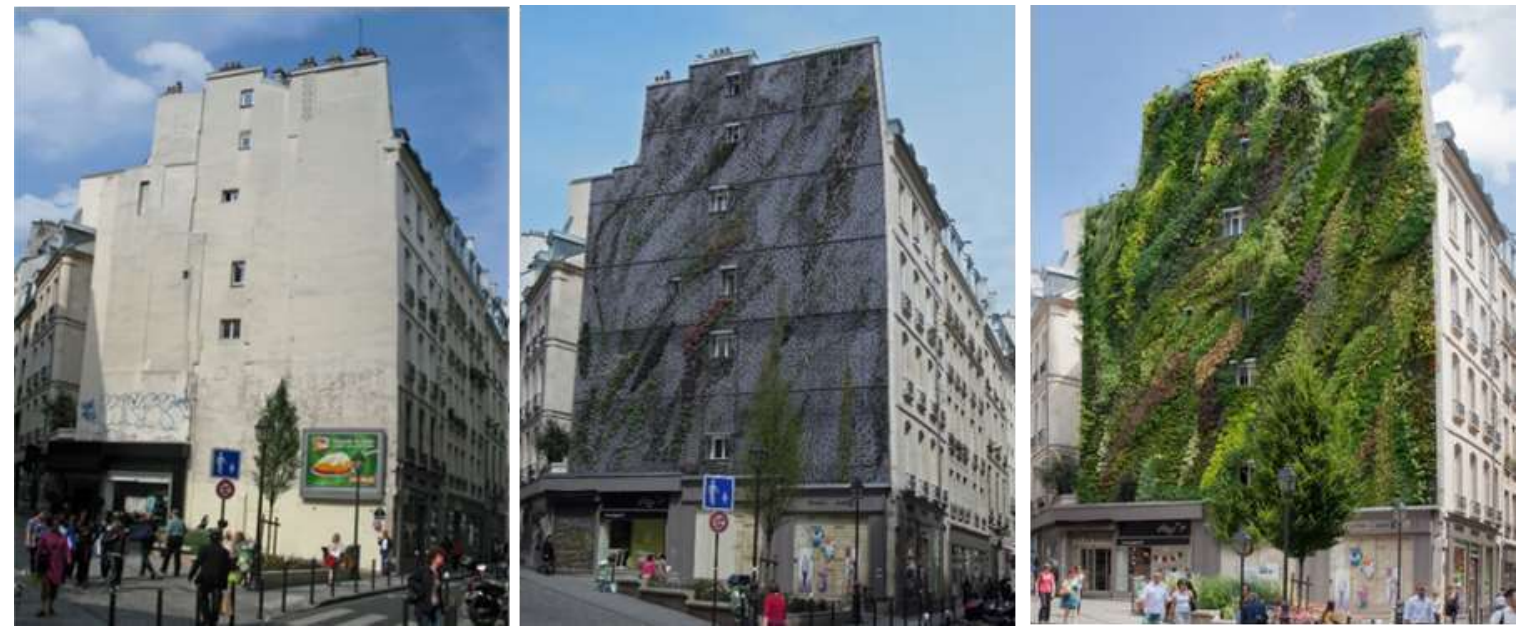

Fig. 7: Green walls - Stages of the Green Oasis D'Aboukir, Paris, France by Patrick Blanc. Source: Dezeen, 2021

All green walls are vertical gardens but not all vertical gardens are green walls.

Main elements of a green wall are plants, planting media, structures that support and attach plants to the façade and irrigation systems (Wood, Bahrami and Safarik, 2014). Green walls have options of camouflage, decorate a building envelop or boundary wall. The stakeholders could also choose when they want to add this to their building. Green walls are listed as two types: as green facades and living walls.

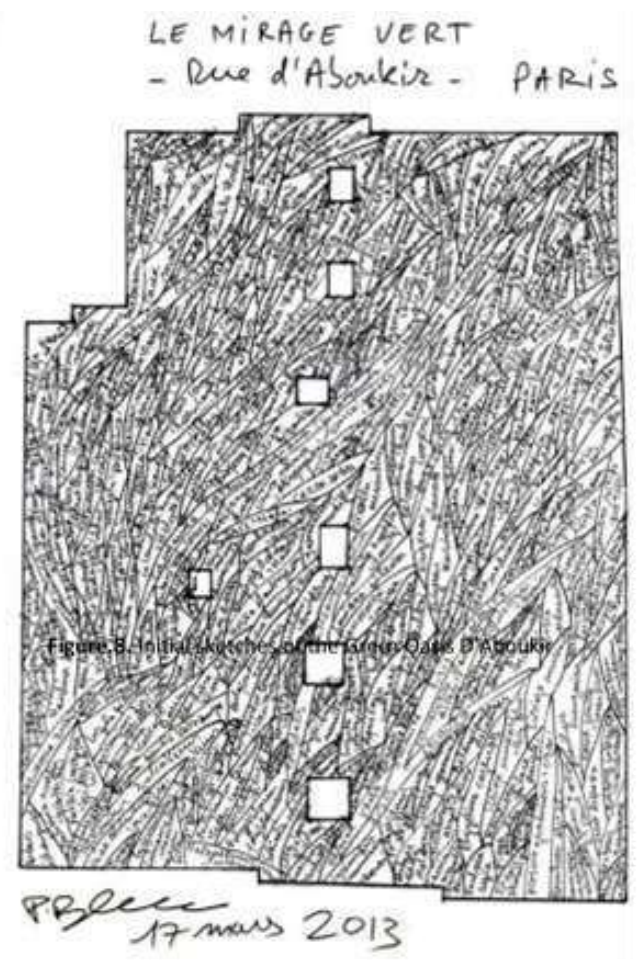

Fig. 8: Initial sketches of the Green Oasis D' Aboukir Paris, France by Patrick Blanc.

Source: Dezeen 


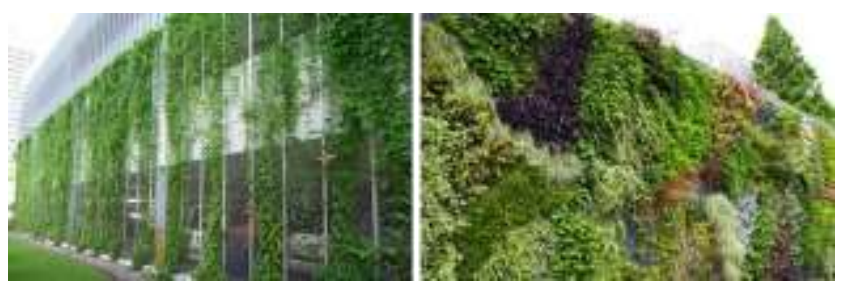

Fig. 9: Green façade and living wall Source: pinterest

\begin{tabular}{|c|c|c|}
\hline & Green facade & Living wall \\
\hline Cost & Less expensive & More expensive \\
\hline Lifespan & $\begin{array}{l}\text { Up to } 100 \text { years and longer in some } \\
\text { historical building covered by } \\
\text { climbing plants/creepers. }\end{array}$ & $\begin{array}{l}\text { 10-15 years lifespan, which is } \\
\text { usually shorter than the building } \\
\text { lifespan. }\end{array}$ \\
\hline Maintenance & $\begin{array}{l}\text { Little maintenance required; plant } \\
\text { pruning and visual inspection. }\end{array}$ & $\begin{array}{l}\text { Higher level of maintenance } \\
\text { required; plant pruning, regular } \\
\text { inspection of façade structural } \\
\text { integrity, and irrigation system } \\
\text { required }\end{array}$ \\
\hline Irrigation & $\begin{array}{l}\text { Natural irrigation by rain, with manual } \\
\text { and automatic irrigation supplemental } \\
\text { systems often provided }\end{array}$ & Automatic irrigation system. \\
\hline Structural support & $\begin{array}{l}\text { Light weight structural support off the } \\
\text { façade(cables, mesh, trellises) }\end{array}$ & $\begin{array}{l}\text { More significant structural support; } \\
\text { additional dead loads on building } \\
\text { structural system need to be } \\
\text { calculated. }\end{array}$ \\
\hline $\begin{array}{l}\text { Thermal performancel } \\
\text { insulation }\end{array}$ & Some thermal benefits & Better thermal benefits. \\
\hline Energy requirements & $\begin{array}{l}\text { Low; plants provide coverage through } \\
\text { natural growth patterns. }\end{array}$ & $\begin{array}{l}\text { Medium; dependence on automatic } \\
\text { irrigation system, increased } \\
\text { maintenance, and more significant } \\
\text { material usage for structural support. }\end{array}$ \\
\hline Best climate zones & All climate zones. & Temperature and hot climate zones \\
\hline
\end{tabular}

Green walls are used for boundary walls and interior as art installations, or as sculpture. 
Green walls are mindfully used by architects, landscape architects and designers in creative and innovative ways to achieve various benefits for the buildings and for the people who live in them. Following images are few international examples.
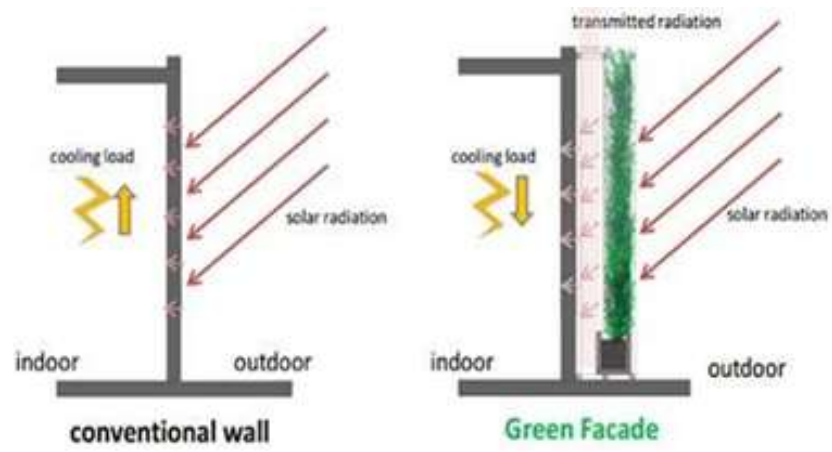

Fig. 10: Sansiri Vertical Living Gallery and office, Bangkok. Source: Inhabitat

At present, green walls have become more than just walls. Sometimes people are unable to access Nature as there are travel restrictions. In a situation where a city is locked down, it is nice to see Nature next door. Covid-19, for an example, has been a deadly virus that affected travel and tourisms in a way that the people were stuck at home. Residents in the city must have appreciated these green walls as these structures produce scent of a forest and work as an air purifier at the same time.

\section{Types and Technologies in Green Wall Installation Systems/Methods}

When considering the technology used in vertical gardening, factors that needs to be considered include: climate (humidity, temperature), orientation, wind, type of vertical gardening system, plants to be used, environmental factors (surrounding ecology), height of building, budget and degree of maintenance (Tan, et al., 2009).Availability of materials and technology, project time line and ability to customize needs to be considered as well.

Newly improved building materials are one aspect of improved vertical garden use. The climbers/ vines are easily supported for longer spans and heights through high tensile steel cables and meshes. Use of geo-textile has prevented roots from rotting and keeps the soil content ideal for growth. Modern automated drip irrigation systems have made it possible to irrigate wider areas and taller structures with minimal human interference, improving cost effective in large projects. Each of the materials changes the aesthetic and functional properties due to the different weight, profile thickness, durability and cost (Perini, et al., 2011).

\section{Green Facades}

'Climbing' and 'hanging' are the two types of green façades. Mostly, creepers and vines are involved in this. The climbing method is divided into direct (traditional) and indirect methods.

Guides and modular trellis. Mostly these are commonly practiced using metal mesh, cable supports or rigid system utilizing two/three-dimensional trellis.

Examples:

-Facade supported green wall with two-dimensional trellis

-Facade supported green wall with three-dimensional trellis 


\section{Living Walls}

These could be achieved by contineous (light weight streams) and modular (Trays, vessel, planter tiles and flexible bags/geo textile pockets) systems. Living walls are divided into two types as 'Hydroponics' and 'Substrate based' types. 'Substrate based' types could be placed vertically, angled or horizontal ways.

\section{Examples:}

-Framed boxes modular living wall

-Wire cage modular living wall

-Perforated boxes modular living wall

-Slanted cell box modular living wall

-Hanging Pocket living wall (Kangaroo pouches)

-Vegetated matt living wall

-Trough planters/treys

In places were soil conditions are not suitable for vegetation, a green wall provides an ideal solution to overcome the issue (Eg- Nepal, Sri Lanka). By associating simple techniques and recycled materials, people have shown that vertical gardens are not a luxury but a necessity in these instances.

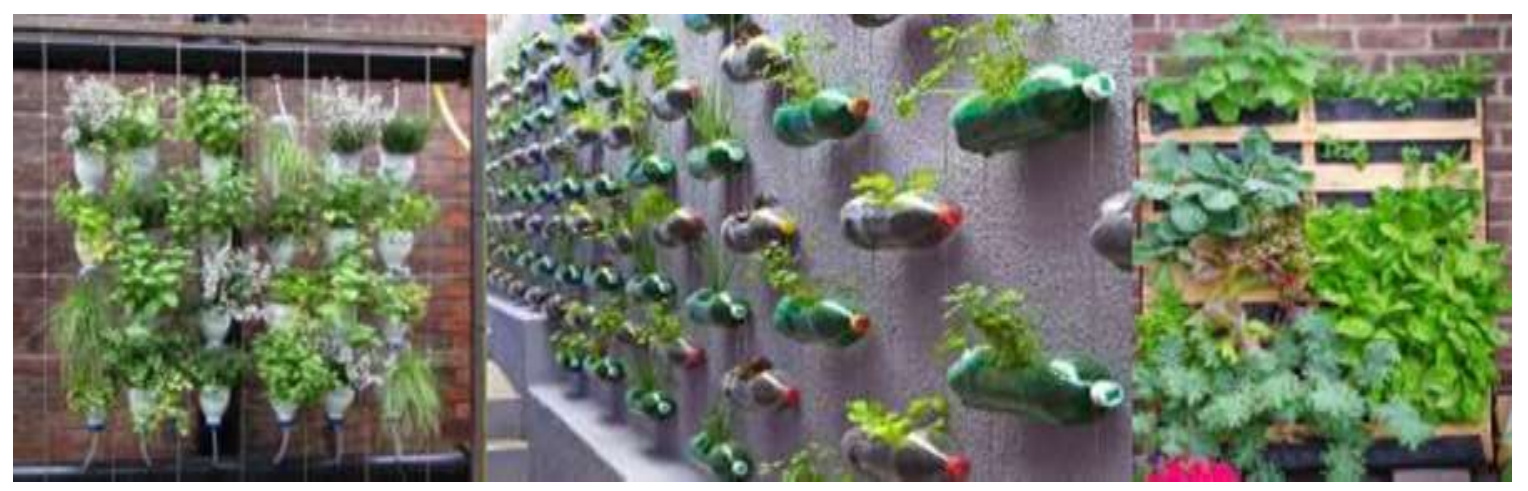

Fig. 11: Do It Yourself (DIY) Type Reuse/Recycle of a Green Wall.

Source: Pinterest 

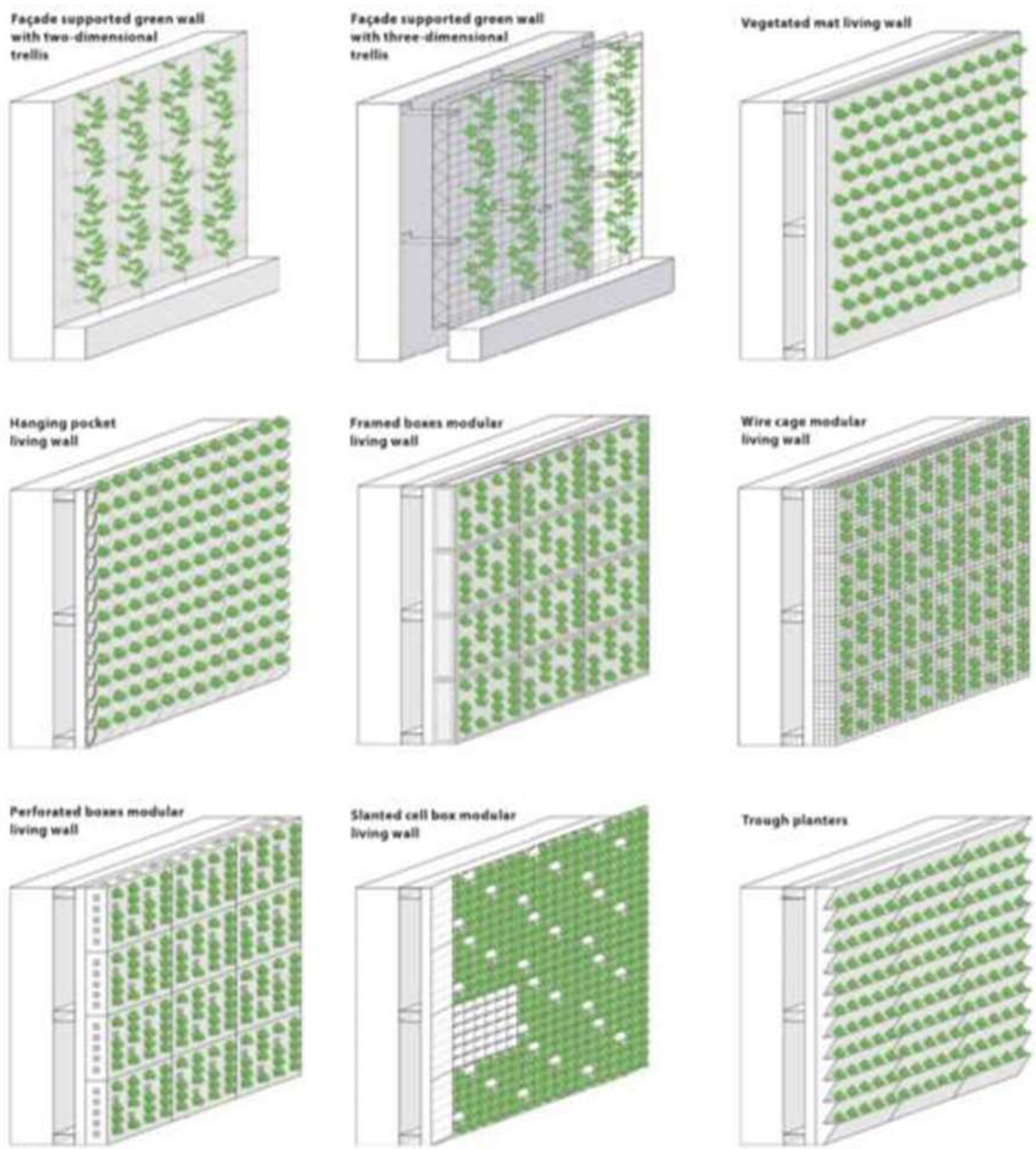

Fig. 12: Types of a green wall Source: by book, the Green walls in High-rise building (2014)

\section{Concepts of Vertical Gardening in building Facades, Applicable to the City of Colombo}

Each building has unique qualities, and these qualities bring attention of the public to places such as entrances. For example, one may have massive arched doorways and towering spires whereas another would pull people in by its welcoming large porch or wide windows. 
Façade is the exterior wall or the face of a building as the word means front wall with an entrance, and it undergoes many architectural treatments unlike others. To design a façade, certain elements must be considered starting from entrance features to types of building materials such as stone, wood frames or brick. It is also important to consider fenestration or the size and positioning of windows. As history suggests, architectural styles have been constantly changing and so were facades.

Scientific discoveries suggest that plants in tropical rainforests are capable of surviving on top strata's of the forests in vertical conditions. Thus, they motivate designers to use them in projects such as Green Office-Meudon, Muharraw, Bharain, and Green Gate.

Plants grown in vertical gardens have a higher success rates of survival. Vines and climbers are another option for gardens that stand vertically but the cost of maintenance would depend on the attributes; for example, height of the building, size \& type of the system, structure of the system etc. Further, lighting a green wall has become a trend worldwide such as back lit (from inside), wall wash (mount light on surface) \& flood lighting (shoot light to surface from a distance).

Colombo has a tropical climate. With high urbanization, Colombo has become a popular place of living but the conversion of green areas to concrete blocks has led to microclimatic changes and phenomenon such as Urban Hear Island (UHI) effects have come to stay. In contrast, green walls, the structures perpendicular to land can reintroduce greenery to the city by integrating vegetation into building envelopes. Besides that, it has other benefits i.e. being an air purifier, long term economic and social benefits such as low energy consumption for cooling systems and sites to visits and enjoy. Buildings also contribute to green economy or vertical gardening would receive credit points under the Sustainable Site category, in Green SL® Rating System of Sri Lanka Green Building Council (SLGBC) for green building certification.

The main purpose of green wall is to replenish air and produce good atmosphere. Colombo has higher number of vehicles that release air filled with carbons. The city is also filled with people who share this air. In addition, people may carry other infections from outer Colombo. Plants in a wall attached to the building should be able to recycle this air and make it disease-free environment to public if correct methodology and plants are available.

There were green walls earlier which had to be taken down due to various reasons (Temple Trees boundary wall, Movepeck Hotel, Hilton Colombo Residencies and Shirohala Petal Guru). The

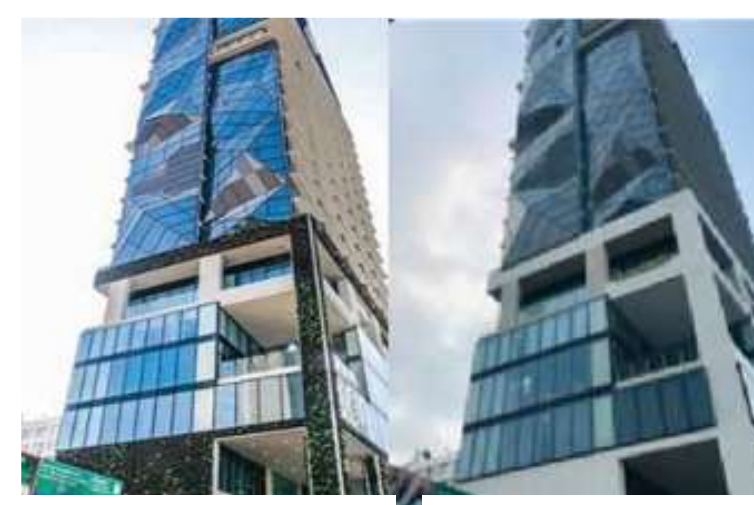

Fig. 13: Movepeck hotel before with green wall. Source: walls pan
Fig. 14: Movepeck hotel after without green wall.

Source: by Author main reason was high maintenance cost.

In 2015, Daily mirror mentioned that the green wall in Temple Trees had cost millions of Rupees per month for maintenance and since it is neither beneficial to the people nor the country, a decision was made to remove it. However, if the green wall was properly designed, there would have been a great overcome and a reduction of cost. 


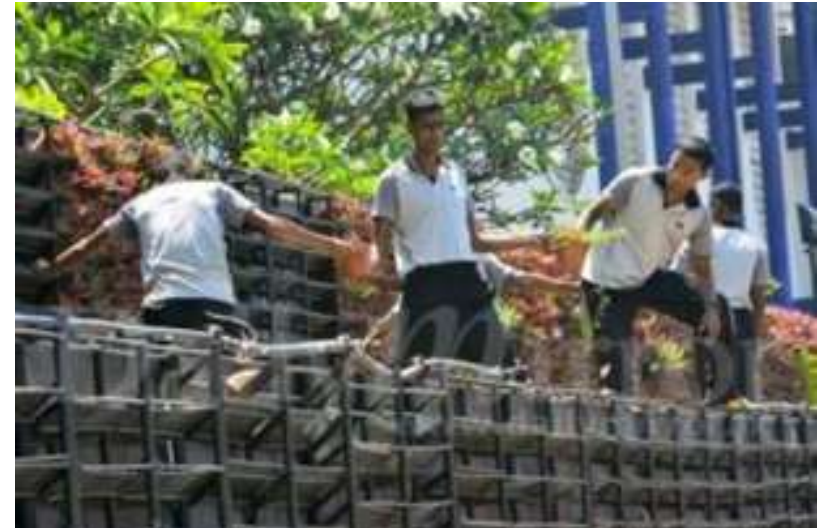

Fig. 15: Removing the Temple Trees Wall Source: Daily Mirror

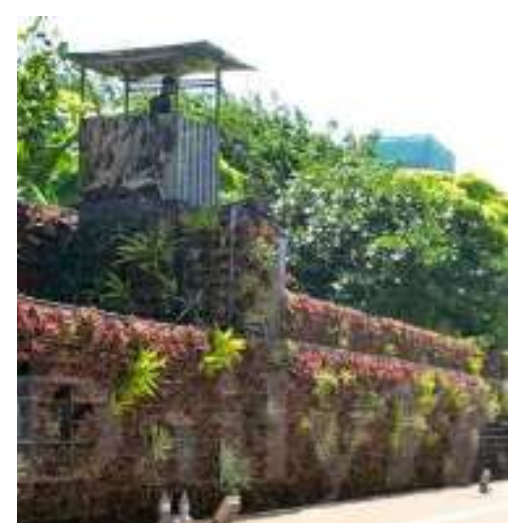

Fig. 16: Temple Trees Green Boundary Wall Source: Daily Mirror

\section{The Role of Green Walls}

A building becomes a green building based on how sustainability is achieved through the pre-construction, construction and post construction phases. A wall can be identified as being sustainable in many ways. Green wall is a type of a wall which has vertical gardening.

There are green categories such as LEED, GREENSL, BREEM, Green star etc. These titles are focused on building sustainability but overall, they contain some consideration on the buildings being green by achieving a certain level of vegetation requirement. Green walls represent that role as an option especially in the urban context within a limited plot.

The achievement of the Green Building title has encouraged growing vegetation, but it seems to have become a trend among the urban dwellers. 18 credits can be achieved by the use of a vertical garden in green rating systems like LEED, which in turn can be used as a marketing strategy. Hotels use LEED Certificates as a marketing tool to emphasize its eco-friendly ventures to create an environmentally conscious image to their clients.

\section{Environmental Sustainability of a Green Wall}

As the interest has been renewed to improve the way of living in a dense city, vertical greening has become a viable option to mitigate air pollution and global warming. A city's image could be enhanced by embracing vertical gardening. A study in Singapore, for example, shows that, as the city grows, vertical landscaping helps people to relieve stress. Moreover, it is one of the best ways to handle Urban Heat Island (UHI) effect. Renewable source harvest, pollution creation, and non-renewable resource depletion are main considerations of environment sustainability.

The construction industry causes environment pollution by consuming 30-40\% energy and natural resources and contribute $30 \%$ to greenhouse gas emission. (Loh, 2008) Sustainable building practices can considerably reduce a building's environmental impact in energy consumption. Covering a building envelope with green vegetation is considered a sustainable construction practice, as green vegetation has a positive performance at energy savings, on asthma patients, and air Quality. According to Susan Loh, energy savings evaluated in the energy consumption of the modular panel living wall materials in the manufacturing process and results demonstrate that the modular panel system requires 3 years to balance the energy consumed in the manufacture process. However, the environmental performance of living walls is influenced by the types of materials and plants chosen for the systems, as well as the external factors, such as climate and the building type. 
Living in a city with polluted or poisonous air is unbearable and lethal. Green walls could mitigate this issue by cleansing the air and killing viruses and bacteria and release antidotes to the environment.

\section{Expectation/Properties of Green Walls Achieving Environmental Sustainability}

There are two ways people could gain benefits from environmental sustainability which are direct and hidden. These green walls could act as the natural air purifier. For a long time, the industry has been heavily relying on fossil fuels which produce an abundance of carbon into the atmosphere after its use by vehicles and factories. Some companies may also acquire certain air purifying products that run on electricity which may come from burning coal or something similar. Green walls would help people to stop using electric purifying machines and as the plants absorb lots of carbons for its photosynthesis, it produces fresh oxygen to the air. This would be a great factor when it comes to people who suffer from COVID-19 and shortness of breath. Common reason for shortness of breath is carbon monoxide, as there are less carbon monoxide air, and more oxygen would allow people to breath easily and fight back the COVID-19 virus.

Apart from explicit benefits, there are a number of implicit benefits as well which may not catch people's eye right away. First, the well-being of people inside the building is important and incorporating green walls provide great atmosphere but the green structure would depend on cost, lifespan, maintenance, irrigation, structural support, thermal performance /insulation, energy requirements and climate zone. It is also mentioned about the percentage of green coverage over total area (Wood, Bahrmi and Safarik, 2014). Wender states that being in touch with Nature, has shown to make people happier in general. It is shown that Nature changes brain chemistry in a positive way, improves mood, decreases stress, and provides opportunities for relaxing the mind. (Wender, 1998). Kellert further strengthens this claim by saying it is the spiritual and psychological benefits of Nature which makes it important for people. According to Browne, creating a landscape with natural elements tend to promote psychological and physical benefits (Kellert, 2007). It is easy to point out how people's chemical reactions come to play with these walls during the lock down caused by the COVID-19.

Vertical gardens are now considered part of the landscape field as there are certain things these green walls express such as environmental perception, climate \& context, wealth $\&$ status (Swaffield,2002). Furthermore, there are rating systems maintained by LEEDS and GreenSL based on management, sustainable sites, energy and atmosphere, materials and resources, indoor environmental quality, innovation and design process, social and cultural awareness.

Criteria for plant selections depend on the types of systems used, the intended planting concept, environmental factors, budget, resilience, disease-tolerance and the expected degree of maintenance (Tan et al., 2009). 


\section{The Research Methodology}

Following table outlines the methodology of research.

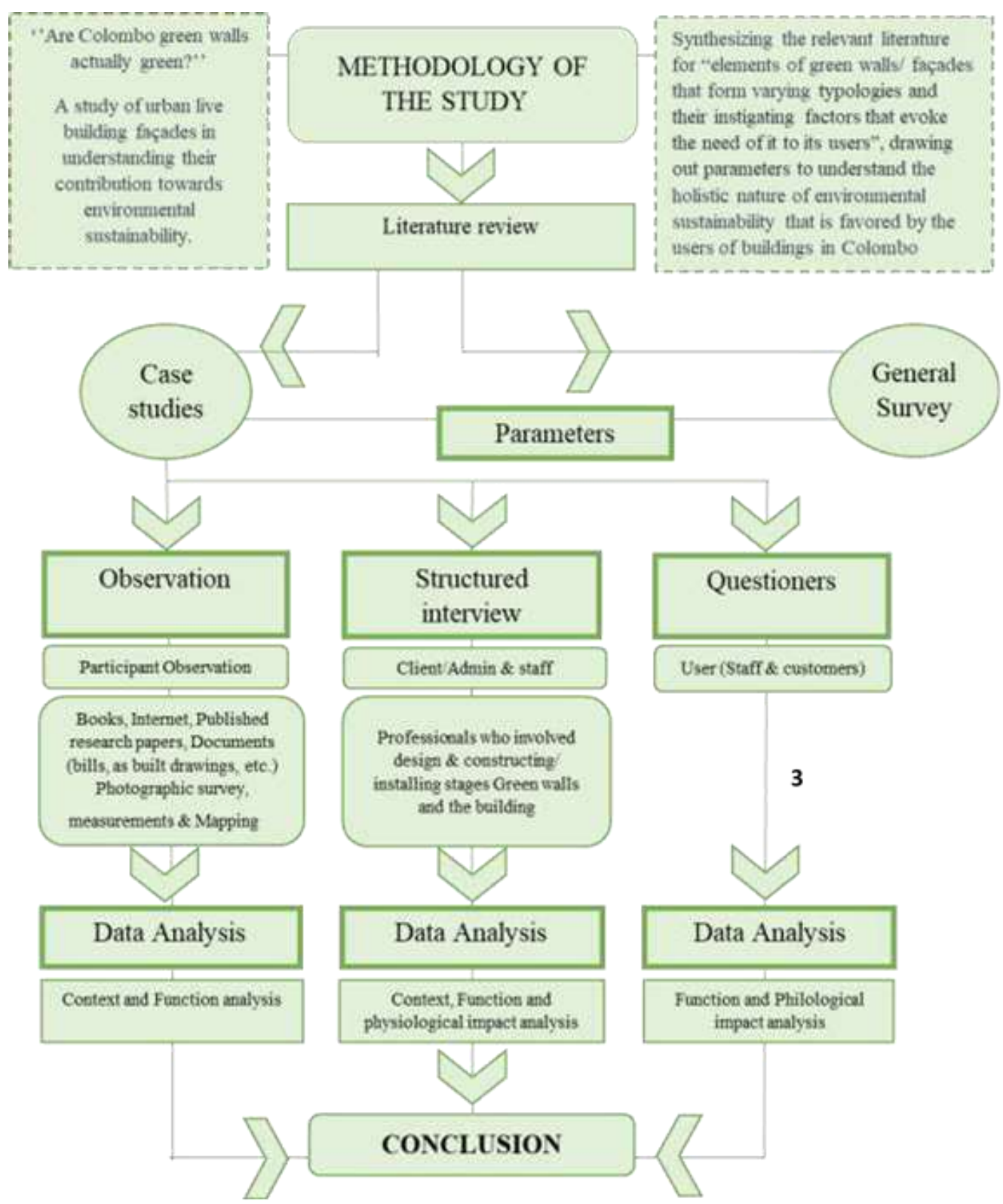

Fig. 17: Diagram of methodology of the study. Source: Author 


\section{Research Approach}

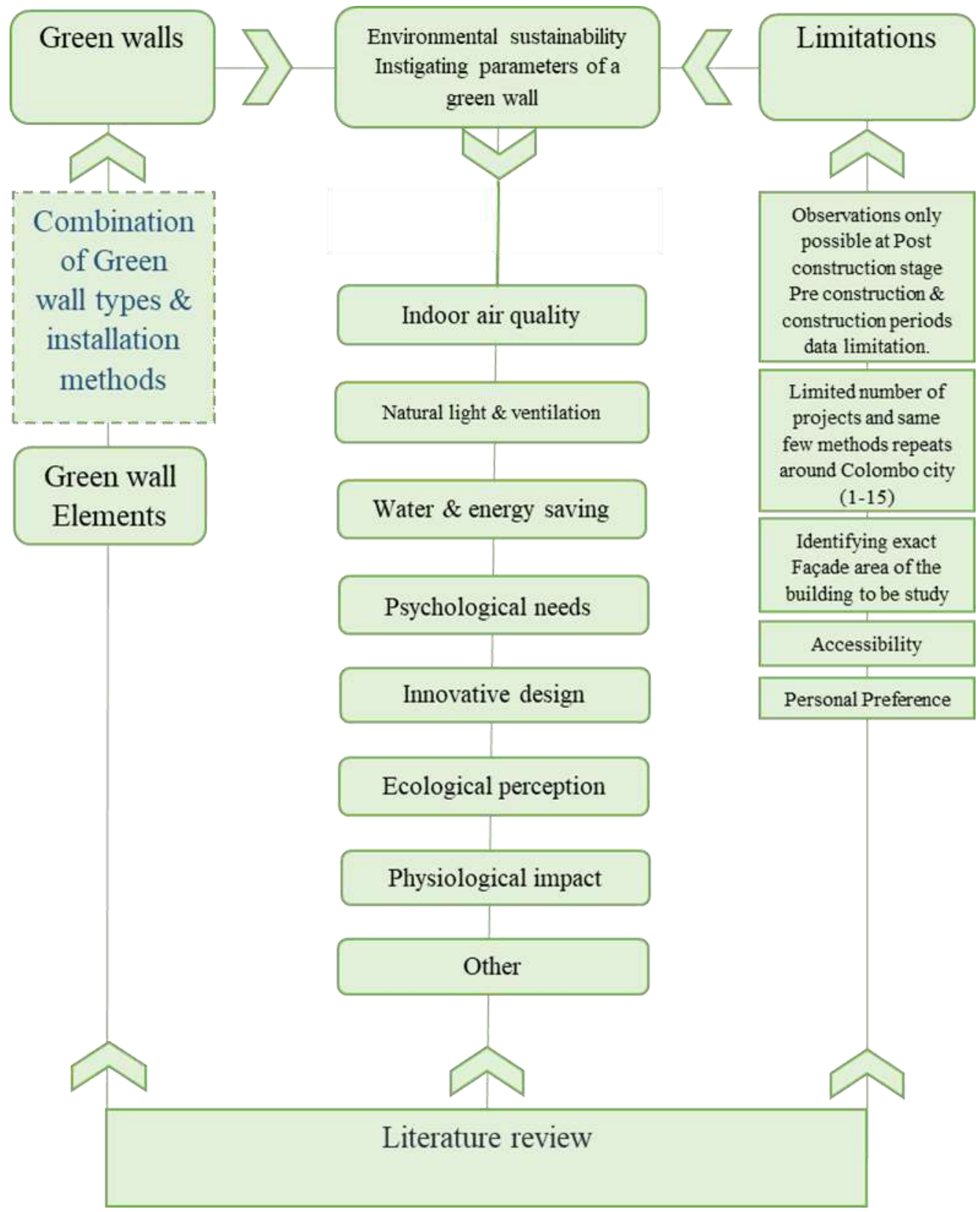

Fig. 18: Diagram of research approach. Source: Author 
Table 1. Post construction stage information detectors of the green wall of Case Studies. Source: Author

\begin{tabular}{|c|c|c|}
\hline $\begin{array}{l}\text { Parameters based on the } \\
\text { environment sustainability } \\
\text { of a green wall }\end{array}$ & Factors to consider & $\begin{array}{l}\text { Method of considering the } \\
\text { factors in a qualitative way }\end{array}$ \\
\hline \multirow[t]{3}{*}{ Response to the site } & Orientation & $\begin{array}{l}\text { Respond to sun path } \\
<\text { Observations }>\end{array}$ \\
\hline & Sound/Acoustic barrier & $\langle$ Observations $\rangle$ \\
\hline & $\begin{array}{l}\text { Responses to climate } \\
\text { (Active/passive) }\end{array}$ & $\begin{array}{l}\text { Shading devices and } \\
\text { effectiveness } \\
\text { Cooling effectiveness } \\
\text { Insulation effectiveness } \\
\text { Wind barrier effectiveness } \\
\text { < Observations > }\end{array}$ \\
\hline \multirow[t]{3}{*}{ Indoor air quality } & $\begin{array}{l}\text { Carbon dioxide mitigation and } \\
\text { oxygen re production }\end{array}$ & $\begin{array}{l}\text { Total area of Vertical greenery } \\
\text { Density of foliage } \\
\text { Size of an average leaf } \\
<\text { Observation }>\end{array}$ \\
\hline & User comfort & $\begin{array}{l}\text { Passive cooling? AC usage? } \\
\text { Fans used? Temperature } \\
\text { difference<Interviews }>\end{array}$ \\
\hline & Dust proof & $\begin{array}{l}\text { Dust layers on the leafs since } \\
\text { the last watering / maintenance }\end{array}$ \\
\hline \multirow[t]{2}{*}{ Natural light \& ventilation } & Natural/artificial ventilation & $<$ Observations \& Interviews $>$ \\
\hline & Natural/artificial lighting & $<$ Observations \& Interviews $>$ \\
\hline \multirow[t]{3}{*}{ Water \& energy saving } & Water supply/Irrigation system & $<$ Observations $>$ \\
\hline & $\begin{array}{l}\text { Embodied energy of the } \\
\text { structure }\end{array}$ & $\begin{array}{l}\text { Green vs. material (plastic, } \\
\text { PVC, aluminum, etc. ) content } \\
\text { per sqm <Observations }>\end{array}$ \\
\hline & Maintenance \& cost & $\begin{array}{l}\text { Plants replacement, replanting, } \\
\text { trimming, chemical use as a } \\
\text { fertilizer or control mites \& } \\
\text { algae } \\
\text { Water \& electricity bills } \\
\text { Average cost to maintain it } \\
\text { monthly } \\
<\text { Observations \& Interviews }> \\
\end{array}$ \\
\hline \multirow[t]{3}{*}{ Innovative design } & Installation method & $<$ Observations $>$ \\
\hline & Local material/local friendly & < Observations $>$ \\
\hline & Possibilities to improve & $\mid<$ Observations $>$ \\
\hline \multirow[t]{3}{*}{ Ecological perception } & Wild life + ecosystem response & <Observations \& Interviews > \\
\hline & Response to biodiversity & $\mid<$ Observations $>$ \\
\hline & Endemic plants or not & <Observations $>$ \\
\hline \multirow[t]{3}{*}{ Physiological impact } & $\begin{array}{l}\text { Customer attraction/image } \\
\text { building }\end{array}$ & $\begin{array}{l}\text { Client, user (staff\& customer) } \\
\text { Time spent near green wall } \\
<\text { Questioner, Observations \& } \\
\text { Interviews }>\end{array}$ \\
\hline & land availability for gardening & $\begin{array}{l}\text { with ample land or lack of land } \\
<\text { Observations }>\end{array}$ \\
\hline & Aesthetic & $\langle$ Observations $>$ \\
\hline
\end{tabular}




\section{Methodology for Analysis of the Case Studies}

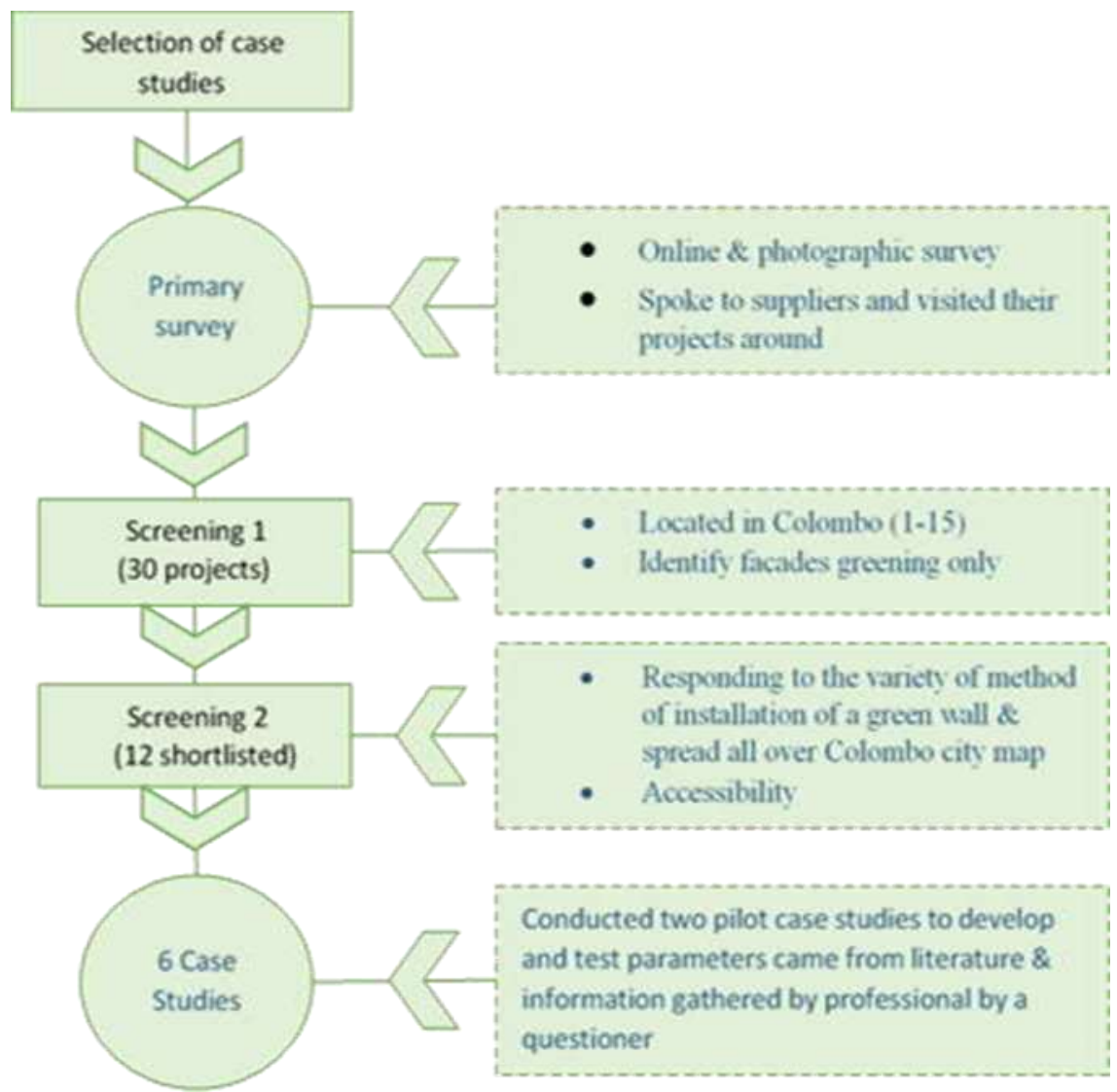

Fig. 19: Diagram of Case Studies Selection of the study. Source: by Author 


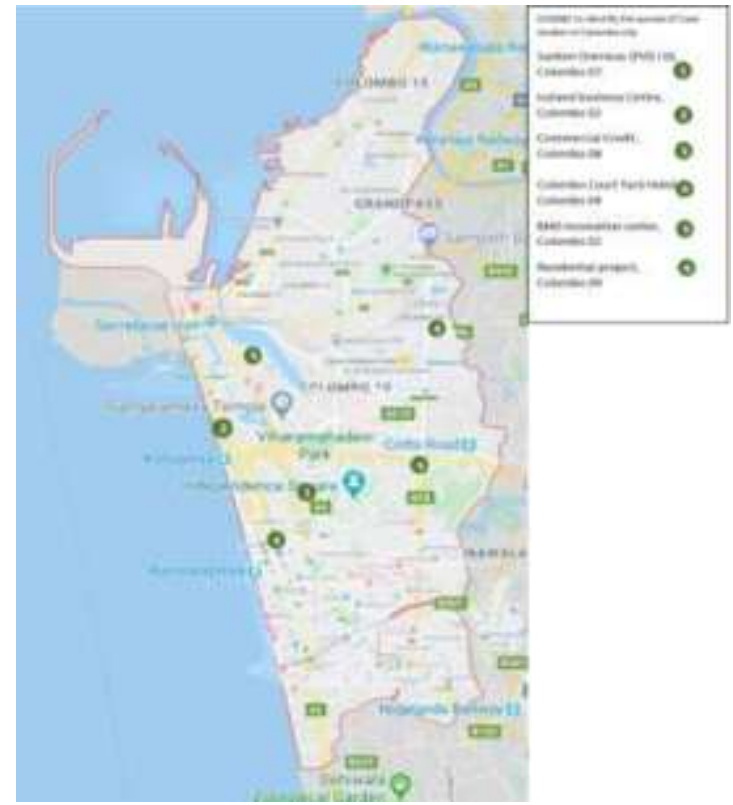

\section{- Justification for the selection of case studies}

Case studies have been selected randomly to cover the Colombo City; didn't change functionally over a year; represented a variety of methods of green walls. Vegetated building Facades having more than 10 sqm area were chosen.

Fig. 20: Case Study Locations

Source: by Author

\section{Findings, Analysis \& Discussion}

\section{Case Study 1 - Sanken Overseas (Pvt) Ltd, Colombo 07.}

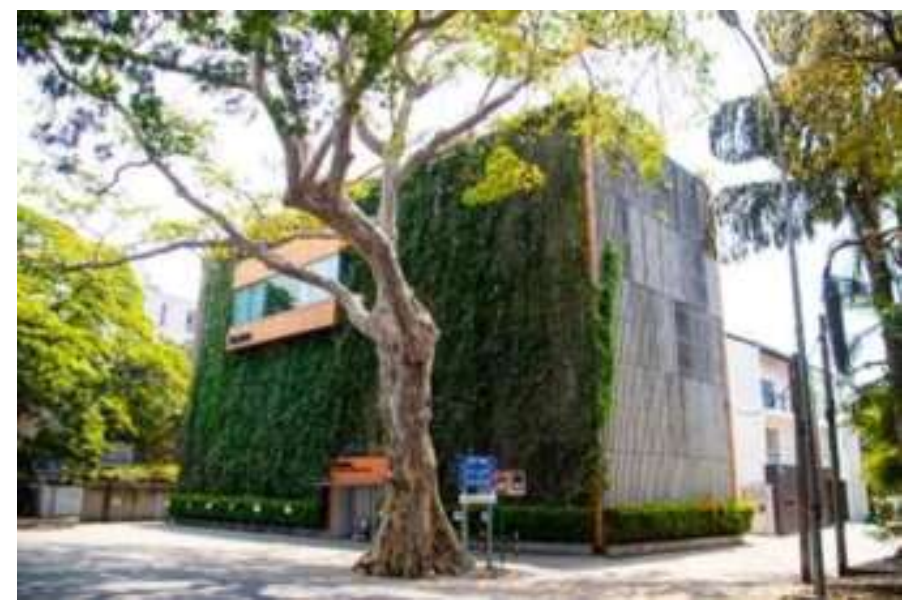

\begin{tabular}{|l|l|}
\hline Company/Building name & Sanken Overseas (Pvt) Ltd \\
\hline Location & Albert Crescent, Colombo 07. \\
\hline $\begin{array}{l}\text { Year of completion } \\
\text { (Building. Green wall) }\end{array}$ & $\begin{array}{l}\text { Renovation was done on 2010 Green wall design } \\
\text { was part of the Renovation design }\end{array}$ \\
\hline Function of the building & Office building \\
\hline Company mission/vision & $\begin{array}{l}\text { Our sevices entail tecleology both cutting edge and eco. } \\
\text { frieblly to provide cer clients senioes beyond expectation. } \\
\text { within be most effective budzet" }\end{array}$ \\
\hline
\end{tabular}




\section{Primary Observation}

Being the city office, the building needed to achieve an iconic character while responding positively to the natural context of the surrounding the area.

\begin{tabular}{|l|l|}
\hline Green wall Type & $\begin{array}{l}\text { Climbing façades -Faced supported green wall } \\
\text { with three dimensional trellis }\end{array}$ \\
\hline Plant types & $\begin{array}{l}\text { Bengal clock vine } \\
\text { (Thumbergia grcandiflora)- sky vine } \\
\text { Blue \& white }\end{array}$ \\
\hline Surface area of the vertical greenery & $\begin{array}{l}197 \text { sqm/205squ (rest of the facade is concrete } \\
\text { fins(vertical strips)) }\end{array}$ \\
\hline Design strategies & $\begin{array}{l}\text { The additive transformation of the facade greening } \\
\text { has changed the whole front façade by the use of } \\
\text { the second skin. The form bas been changed from } \\
\text { a horizontally emphasized building to a more } \\
\text { vertically emphasized building (Visually taller). } \\
\text { The second skin which is part of the vertical } \\
\text { garden bas been used positively to create a unique } \\
\text { character for the building. This has been done } \\
\text { using two methods. One is by the use of the } \\
\text { second skin as an element emphasizing verticality. } \\
\text { Secondly, trailing plants through the second skin } \\
\text { to bang vertically downwards emphasizes this } \\
\text { effect furthered. }\end{array}$ \\
\hline Other observations & $\begin{array}{l}\text { Less maintenance, once in six months main } \\
\text { trimming and fertilizer provided. Watering the } \\
\text { plant daily. }\end{array}$ \\
\hline $\begin{array}{l}\text { Insects, ants, butterflies \& spiders habitats are } \\
\text { developing. Little birds nest was observed.as they } \\
\text { used flowering plant changing façade is according. }\end{array}$ \\
\hline requirement
\end{tabular}

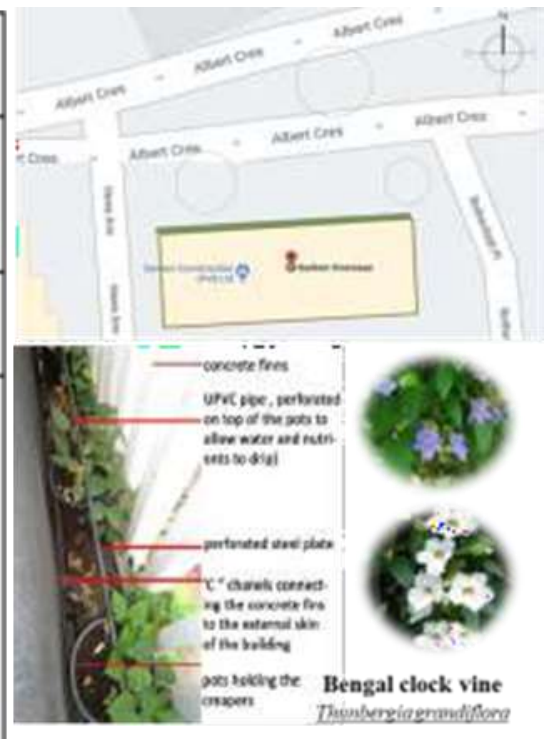

\section{Placement Aspiration \& Method}

This was design-and-built by Sankan team. Archt. Lal Thennakoon and Eng. Buwaneka Bihanlal Kulupana were leading the team. The outer structure of the double skin is made of concrete fins. As this is a renovation, the load from the addition of the vertical garden is carried down through these fins. Hedera helix creeper placed in pots are encouraged to merge through the gaps in the façade and drip down. Built-in cement troughs are also in place at the top and the bottom of the outer skin structure. Although not functioning now, a ground-up flood-light system is expected to light up the vertical garden. When renovating the building, the vertical garden was introduced to reduce dust and noise pollution, and to create a better working environment for the occupants. 


\begin{tabular}{|c|c|c|}
\hline 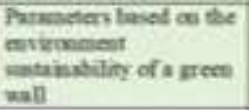 & Factars to coensier & Retienv Cament: \\
\hline \multirow[t]{3}{*}{ Respcense to the site } & Oriantaticen & 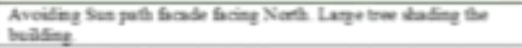 \\
\hline & $\begin{array}{l}\text { Sound/Acoustic } \\
\text { barrier }\end{array}$ & 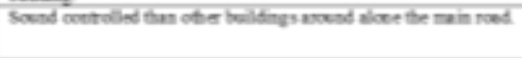 \\
\hline & $\begin{array}{l}\text { Respoese climate } \\
\text { (Active passive) }\end{array}$ & 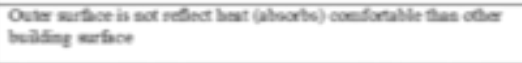 \\
\hline \multirow[t]{3}{*}{ Indoct air quality } & $\begin{array}{l}\text { Carben dionide } \\
\text { mitigation and } \\
\text { axygen reproductice }\end{array}$ & 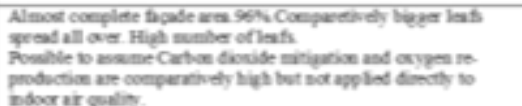 \\
\hline & User Confort & 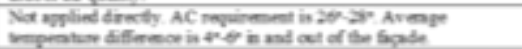 \\
\hline & Dust proof & 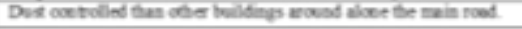 \\
\hline \multirow[t]{2}{*}{$\begin{array}{l}\text { Natural lupht \& } \\
\text { ventibtion }\end{array}$} & $\begin{array}{l}\text { Natural artificial } \\
\text { ventilation }\end{array}$ & 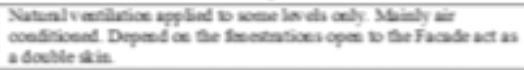 \\
\hline & $\begin{array}{l}\text { Natural artíicial } \\
\text { liebting }\end{array}$ & 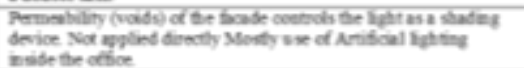 \\
\hline \multirow[t]{3}{*}{ Water \& anergy saving } & $\begin{array}{l}\text { Water supbly/ } \\
\text { Imigation system }\end{array}$ & 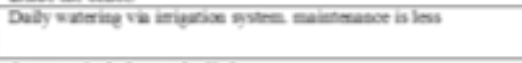 \\
\hline & $\begin{array}{l}\text { Enbodied energy of } \\
\text { the structure }\end{array}$ & 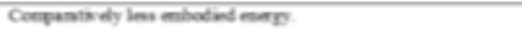 \\
\hline & Maintesance \& cost & 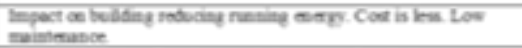 \\
\hline \multirow[t]{3}{*}{ Inbovative design } & Installation method & 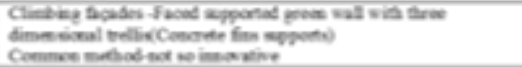 \\
\hline & $\begin{array}{l}\text { Local materiahocal } \\
\text { friesdly }\end{array}$ & Na cowidend \\
\hline & $\begin{array}{l}\text { Possibulities to } \\
\text { improve }\end{array}$ & 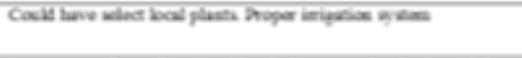 \\
\hline \multirow[t]{3}{*}{ Ecologeical perception } & $\begin{array}{l}\text { Wrid life + econytem } \\
\text { respoese }\end{array}$ & 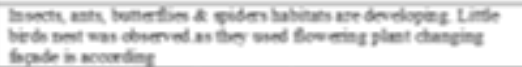 \\
\hline & $\begin{array}{l}\text { Respoese to } \\
\text { Biadivervity }\end{array}$ & 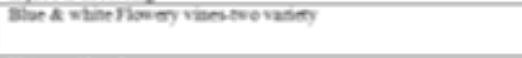 \\
\hline & Eodemic plats of aod & Sarocindend \\
\hline \multirow[t]{3}{*}{ Fyswological ampact } & $\begin{array}{l}\text { Customer attracticel } \\
\text { image bralding }\end{array}$ & 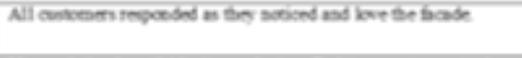 \\
\hline & $\begin{array}{l}\text { land wailabelity for } \\
\text { gardeaing. }\end{array}$ & 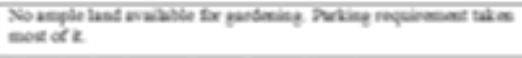 \\
\hline & Aesthetic & 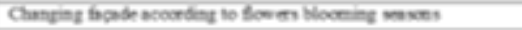 \\
\hline
\end{tabular}
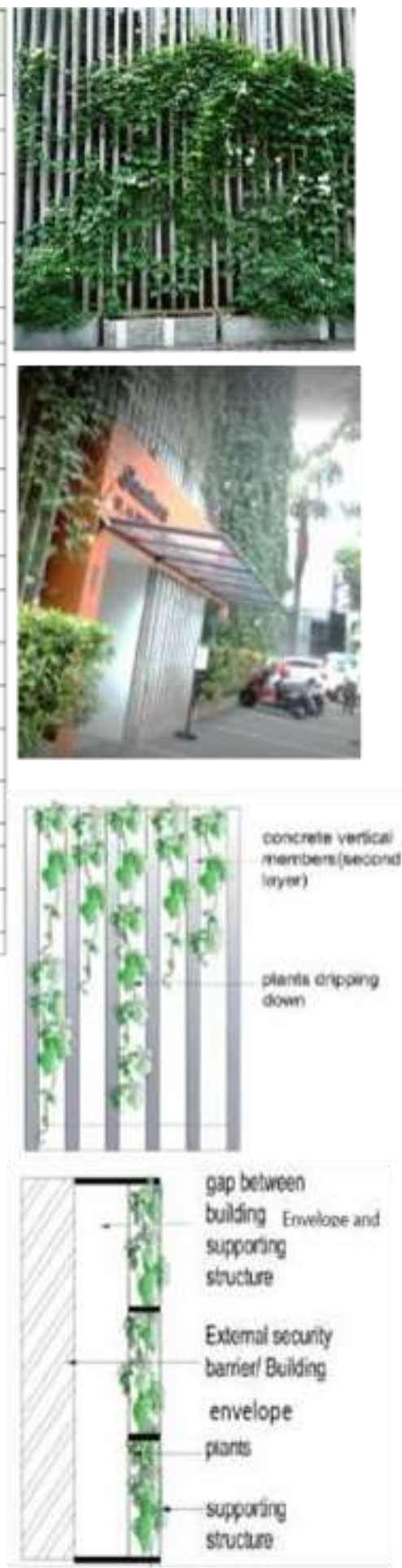


\section{Data Analysis \& Conclusion}

An existing tree shades the building façade actively responding to the microclimate. As most of the building is air conditioned and has artificially-lit office spaces, the green wall is not involved directly in providing either natural ventilation, lighting or indoor air quality. However, it is incorporated at upper levels. Facade acts as a sound and dust barrier.

Daily watering via an irrigation system makes maintenance easier. This has comparatively less embodied energy and impact on the building reducing running energy consumption. It provides a habitat for tiny creatures. Flowering makes the façade change and become aesthetically pleasing.

\section{Case Study 2 - Iceland Business Centre, Colombo 03}

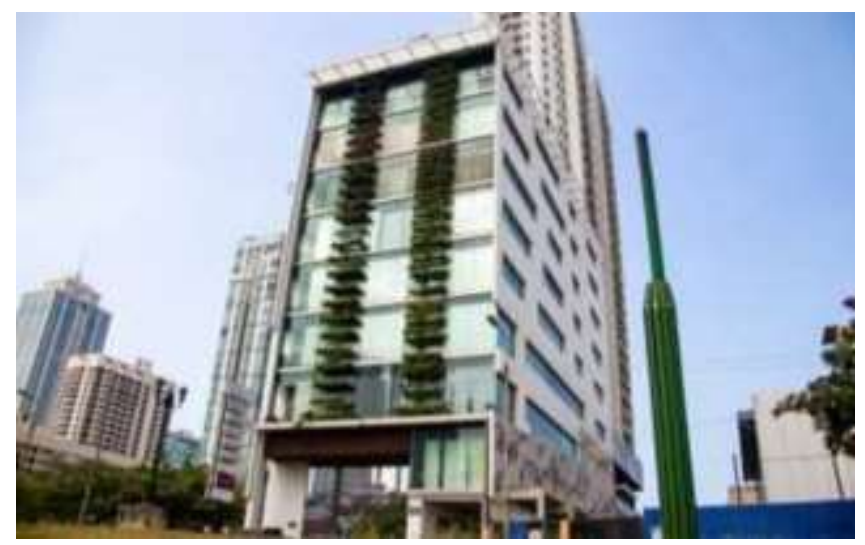

\begin{tabular}{|c|c|}
\hline Consong Bubling same & Icelied bunisess Cemte \\
\hline Lecation & Slave Iland Colombo 03 \\
\hline $\begin{array}{l}\text { Year of coevietion } \\
\text { (Building, Geen wall) }\end{array}$ & 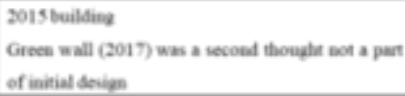 \\
\hline Function of the builling & Othes buibling (multriple congraies) \\
\hline Conspary miniosvivice & 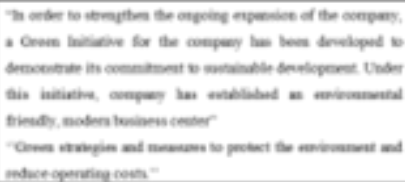 \\
\hline
\end{tabular}




\section{Primary Observation}

\begin{tabular}{|c|c|}
\hline Green wall Type & $\begin{array}{l}\text { Facod integratod living wall- } \\
\text { Trouph planters (movable) }\end{array}$ \\
\hline Plant types & 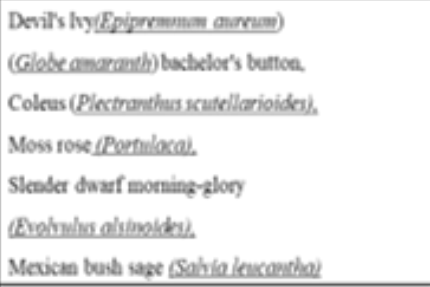 \\
\hline $\begin{array}{l}\text { Surface area of the vertical greenery } \\
\text { compured to total building facade }\end{array}$ & $42 \mathrm{sqp} / 315 \mathrm{sqm}$ (rest of the frade is glass) \\
\hline Desien stratcegics & 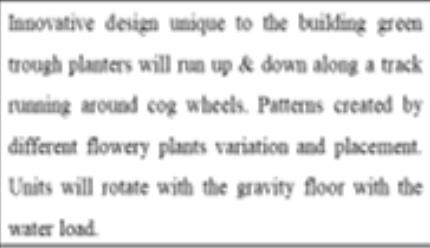 \\
\hline Maintenusce royuirement & $\begin{array}{l}\text { Twice a month. (Trimming and chemical } \\
\text { fatilizer) Water rupply and maintensaxe dooe } \\
\text { from the roof slab. }\end{array}$ \\
\hline Other observations & $\begin{array}{l}\text { Moving struxtare by cog whel and chain sytem. } \\
\text { Variety of plast can be archived. Changing } \\
\text { focadex. }\end{array}$ \\
\hline
\end{tabular}

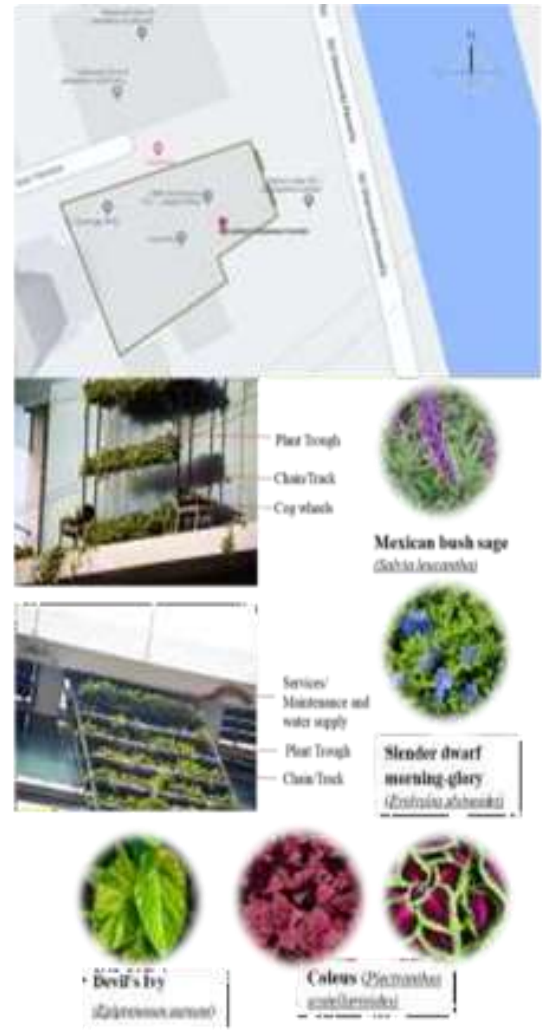

This green wall is an afterthought. They have thought of the mechanism of movable façades and changing facades by using different plants from time to time. 
Cities People Places; Vol. 5, Issue 1: June, 2021

\begin{tabular}{|c|c|c|}
\hline $\begin{array}{l}\text { Parameters based on } \\
\text { the environment } \\
\text { sustainability of a green } \\
\text { wall }\end{array}$ & Factors to consider & Reviews/Comments \\
\hline \multirow[t]{3}{*}{ Response to the site } & Orientation & Facsde facing North East (ce tbe sun path) to direct sua lighte. \\
\hline & Sound/Acoustic barrier & Not imohed directly \\
\hline & $\begin{array}{l}\text { Response to climate } \\
\text { (Active passive) }\end{array}$ & $\begin{array}{l}\text { No impact ce redocing beat gain. } \\
\text { Found no temperature differesce in and out of the facade }\end{array}$ \\
\hline \multirow[t]{3}{*}{ Indoor air quality } & $\begin{array}{l}\text { Carbon dioxide mitigation } \\
\text { and oxygen re production }\end{array}$ & $\begin{array}{l}\text { Not effective esough Average leaf size. Number of lewes are also } \\
\text { compuratively less. Oreeneny is only } 15 \% \text { of be facade. }\end{array}$ \\
\hline & User comfort & $\begin{array}{l}\text { Not imokved directly no major temperatare difference identifies in } \\
\text { and out of the facade }\end{array}$ \\
\hline & Dust proof & Not imoked directly \\
\hline \multirow[t]{2}{*}{$\begin{array}{l}\text { Natural light \& } \\
\text { ventilation }\end{array}$} & $\begin{array}{l}\text { Natural/artificial } \\
\text { ventilation }\end{array}$ & Not imohed directly.AC requirement is $22^{\circ} .24$. \\
\hline & Natural/artificial lighting & $\begin{array}{l}\text { Not effective enough. Mostly wse of Artificial lighting inside the } \\
\text { office. impact os people wto works near facade when there's no } \\
\text { blinds }\end{array}$ \\
\hline \multirow[t]{3}{*}{ Water \& energy saving } & $\begin{array}{l}\text { Water supply/ Irrigation } \\
\text { system }\end{array}$ & $\begin{array}{l}\text { Daily Watering accordiag to a systematic way. It does not use } \\
\text { electricity to rotate planters It is marrally or grwity flow } \\
\text { operated when urter is filled in to planter. }\end{array}$ \\
\hline & $\begin{array}{l}\text { Embodied energy of the } \\
\text { structure }\end{array}$ & Comparatively high enbodied energy. \\
\hline & Maintenance $\&$ cost & High maintertabce ied coit \\
\hline \multirow[t]{3}{*}{ Innovative design } & Installation method & $\begin{array}{l}\text { Inmovative mebod movable Faced integrated living wall-Trough } \\
\text { planters (movable) }\end{array}$ \\
\hline & $\begin{array}{l}\text { Local material/ local } \\
\text { friendly }\end{array}$ & Not cossidered \\
\hline & Possibilities to improve & Redree, Reuse concept wben replaxing purts \\
\hline \multirow[t]{3}{*}{ Ecological perception } & $\begin{array}{l}\text { Wild life + ecosystem } \\
\text { response }\end{array}$ & $\begin{array}{l}\text { Not effective esough Coulde't idestify any living creature in the } \\
\text { structure. }\end{array}$ \\
\hline & Response to biodiversity & $\begin{array}{l}\text { At last observation cae plant type was ead but throughout past } \\
\text { few months at initial observation respoeded to variety of plants } \\
\text { landscape service provider mention several plant types which they } \\
\text { tane been wed after installation. }\end{array}$ \\
\hline & Endemic plants or not & Not considered \\
\hline \multirow[t]{3}{*}{ Physiological impact } & $\begin{array}{l}\text { Customer attraction/ } \\
\text { image building }\end{array}$ & $\begin{array}{l}\text { Most of the customers responded as they didn't notice the facade } \\
\text { and it belped give an image to overall building but placed beyond } \\
\text { eye level. Aded points ubder vegetation criteria to achieve Oreen } \\
\text { titles A wards. }\end{array}$ \\
\hline & $\begin{array}{l}\text { land availability for } \\
\text { gardening }\end{array}$ & $\begin{array}{l}\text { Not ample land wailable for gardening. Froat area gooe for } \\
\text { purking (paved) requirement. }\end{array}$ \\
\hline & Aesthetic & $\begin{array}{l}\text { Variety of plants coeld be achieved Changing plants cece in two } \\
\text { months. }\end{array}$ \\
\hline
\end{tabular}

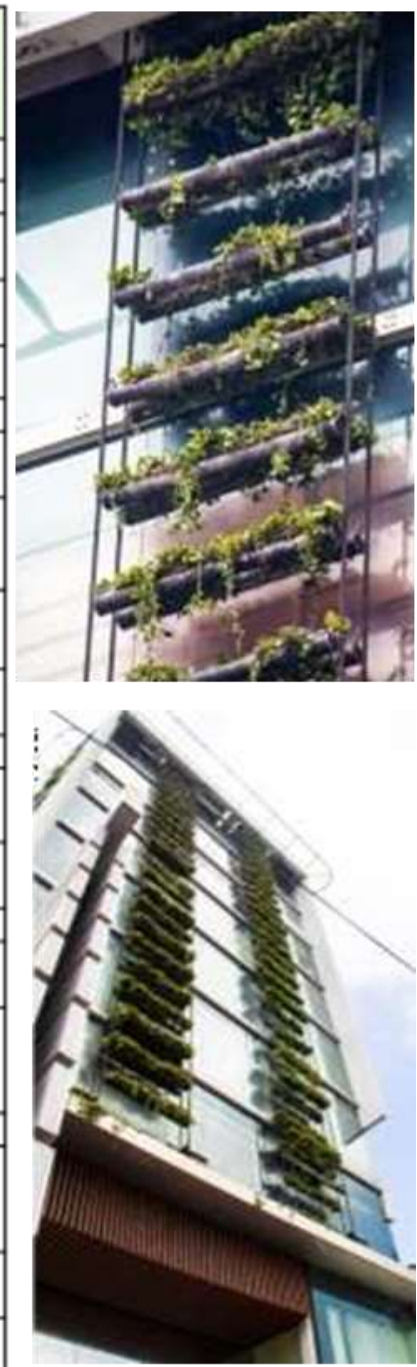

\section{Data Analysis \& Conclusion}

This is an innovative idea of placing and maintaining a green wall. All the services including maintenance are done from the roof top level. Daily watering is done in a systematic way.

It is only 42 sqm out of $315 \mathrm{sqm}$ facade area; the rest of the façade is glass. The green facade area is not to give a proper impact on cutting sunlight. It does not effectively help to reduce the electricity cost to run the air conditioning behind the glass facade. There is no visual connection between the green facade and the interior of the office. Those who are close to the façade also use blinds during the daytime to cut off sunlight. This green wall neither produces any microclimatic impact, nor effect the indoor air quality, natural ventilation or light. 


\section{Case study 3 - Commercial Credit City Office, Colombo 08}

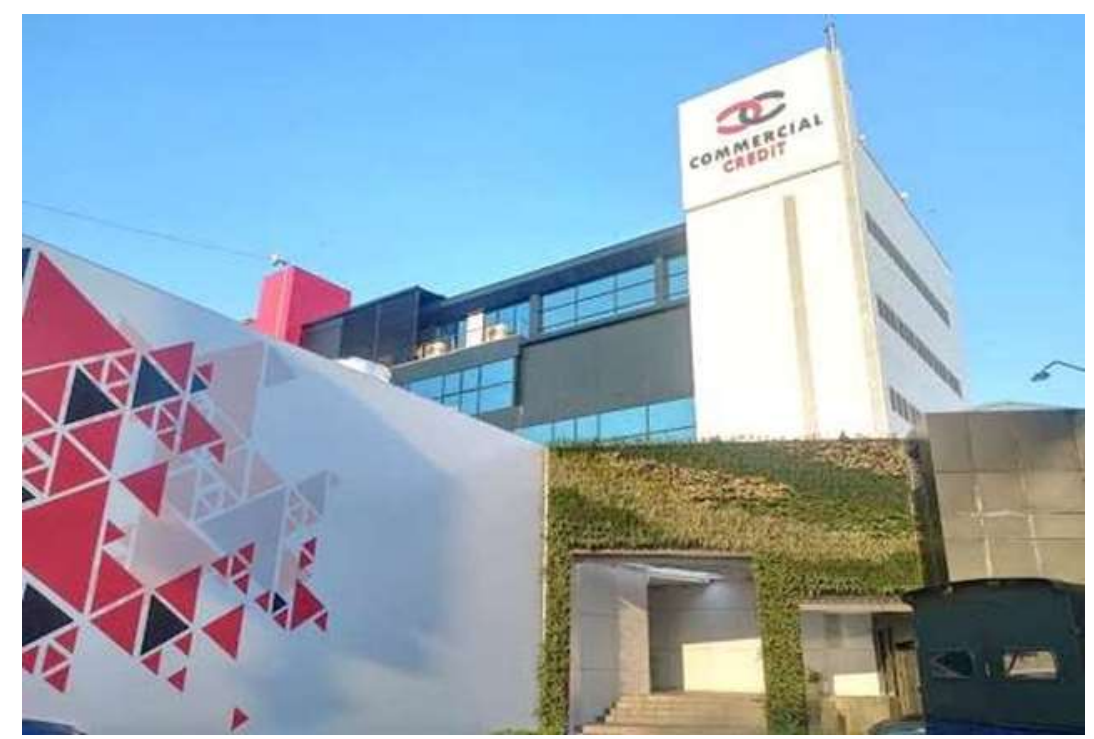

\begin{tabular}{|c|c|}
\hline Company/Building name & Commercial Credit City Office \\
\hline Location & Colombo 08,Borella \\
\hline $\begin{array}{l}\text { Year of completion } \\
\text { (Building. Green wall) }\end{array}$ & $\begin{array}{l}\text { 2018-Rebranding made to renovate the building. } \\
\text { Green wall came with that. }\end{array}$ \\
\hline Function of the building & Bank / Finance /Office \\
\hline Company mission/vision & 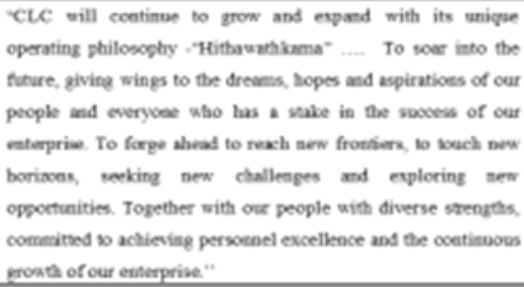 \\
\hline
\end{tabular}

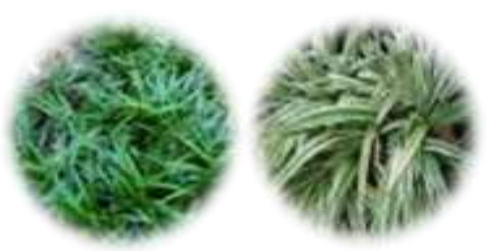

Mondo grass

Qpolilogegari

(Draw moodo grass, Vrriegated Moodo Grass)

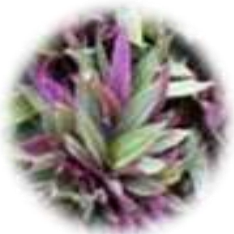

Roheo

Thadeconuriassonhocen:

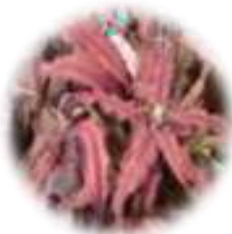

Earth Star

Contanthus Binitrates)

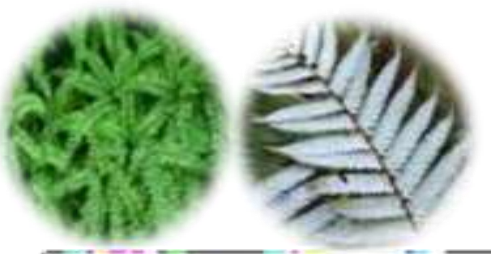

Ferns

Nicpurolegir malfitiol

(Poly fens det fens, slver fens) 


\section{Primary Observation}

\begin{tabular}{|c|c|}
\hline Green wall Type & $\begin{array}{l}\text { Faced inteyrated lining wall- slened cell moduler } \\
\text { Ining box pots }\end{array}$ \\
\hline Plant types & 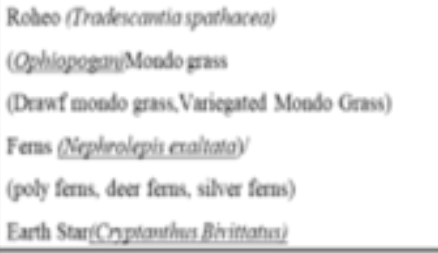 \\
\hline $\begin{array}{l}\text { Surface area of the ventical prenery } \\
\text { coeppared to total builling facade }\end{array}$ & $36 \mathrm{sqm} / 108 \mathrm{sqm}$ \\
\hline Design strategies & $\begin{array}{l}\text {-Pattern was actieved by using variation of plants } \\
\text { and color combinatioe of actual plasts themselves. } \\
\text {-faxing to sulight } \\
\text {-Drip irrigation system for the supply of water. }\end{array}$ \\
\hline Maintenuase requiremest & 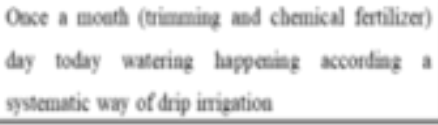 \\
\hline Other obvenations & $\begin{array}{l}\text { Couldn't find major living creature in the facade } \\
\text { maybe because it is fully beat op with direst } \\
\text { sunlight in the dry time. }\end{array}$ \\
\hline
\end{tabular}

Placement Aspiration \& Method Commercial Credit is a bank which recently rebranded and gave a new look. It is trying to restore all outlets a new brand image. The bank considers the building façade and the placement of green wall as a design requirement and there is a minimum percentage to achieve as a green wall in each outlet façade. As the first attempt of their new concept, this green wall was built at the entrance to emphasize it and to get the attention of the customers.

It comes from the first stage of the design and they have considered low maintenance and commonly found plants but the structure has been based directly on the supplier's recommendation.

\begin{tabular}{|c|c|c|}
\hline 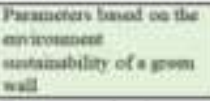 & 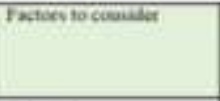 & Retwave canenth \\
\hline \multirow[t]{3}{*}{ Kespoese to the site } & Oriedation & 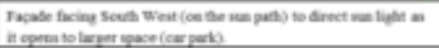 \\
\hline & 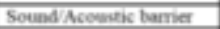 & 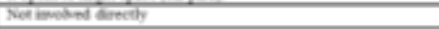 \\
\hline & $\begin{array}{l}\text { Response to climinte } \\
\text { (Active passive) }\end{array}$ & 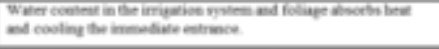 \\
\hline \multirow[t]{3}{*}{ Indoot air qualing } & $\begin{array}{l}\text { Combon diavide } \\
\text { mitigntion and exyen re } \\
\text { production }\end{array}$ & 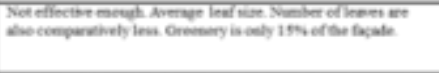 \\
\hline & Uher Comfert & 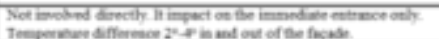 \\
\hline & Dast proot & 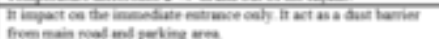 \\
\hline \multirow[t]{2}{*}{$\begin{array}{l}\text { Nantand ligher \& } \\
\text { veatilatioe }\end{array}$} & $\begin{array}{l}\text { Nahural artificial } \\
\text { vertilution }\end{array}$ & 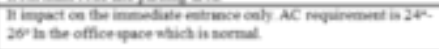 \\
\hline & $\begin{array}{l}\text { Natural artificial } \\
\text { lighting }\end{array}$ & 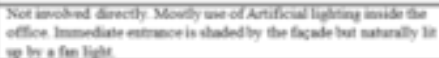 \\
\hline \multirow[t]{3}{*}{ Wale \& enery aning } & $\begin{array}{l}\text { Water supply/linigatices } \\
\text { sytem }\end{array}$ & 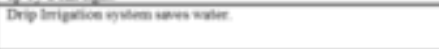 \\
\hline & $\begin{array}{l}\text { Embodied energy of the } \\
\text { trustuse }\end{array}$ & 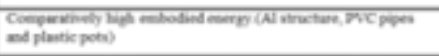 \\
\hline & Mtaintenasace \& cont & 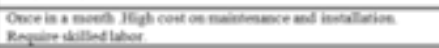 \\
\hline \multirow[t]{3}{*}{ Thaovative design } & Installatice method & 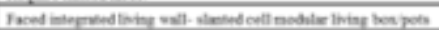 \\
\hline & $\begin{array}{l}\text { Leal material local } \\
\text { triestly }\end{array}$ & Nercennibered \\
\hline & Posudtalities to improve & 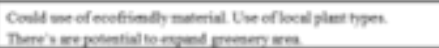 \\
\hline \multirow[t]{3}{*}{ Ecological perception } & $\begin{array}{l}\text { Whid life + asowitem } \\
\text { resprese }\end{array}$ & 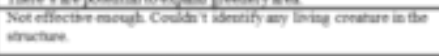 \\
\hline & Rerpones to biotwerving & 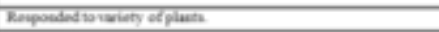 \\
\hline & Enokenic plats of not & Terecentional \\
\hline \multirow[t]{3}{*}{ Figsiological impact } & $\begin{array}{l}\text { Cuntomer } \\
\text { artractioesimape } \\
\text { bailding }\end{array}$ & 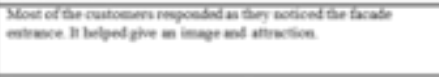 \\
\hline & $\begin{array}{l}\text { lead wivilability for } \\
\text { gandering }\end{array}$ & 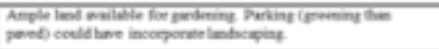 \\
\hline & Aenthatic & 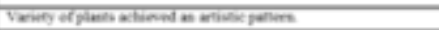 \\
\hline
\end{tabular}

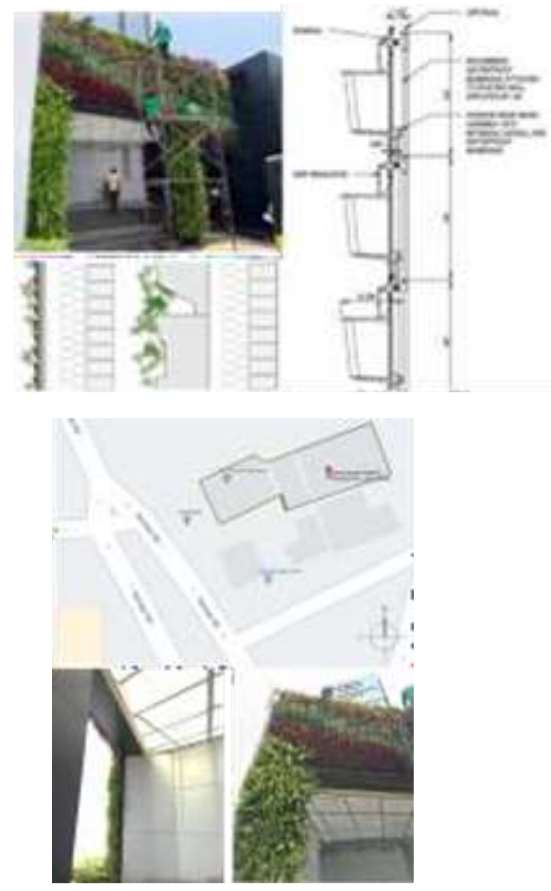




\section{Data Analysis \& Conclusion}

Only 36 sqm is greenery while rest of the facade which is more than $2 / 3$ is Aluminum cladding and concrete walls. The greenery surface and bthe background incorporates plastic modular pots and PVC pipes for the irrigation system. It acts as completely solid structure imported and assembled in this location. The embodied energy is high. This is not environmentally friendly nor locally produced. It's facing the open area and the façade is exposed to direct sunlight. This wall acts as a dust and sound barrier and provides shade to the entrance area. According to the observations, it's due to water and foliage. It absorbs the heat, unlike the cladding. It is thus aesthetically pleasing. This design has encouraged the use of a variety of plants. It is hard to find any creatures in it.

\section{Case Study 4 - Colombo Courtyard Hotel, Colombo 04}

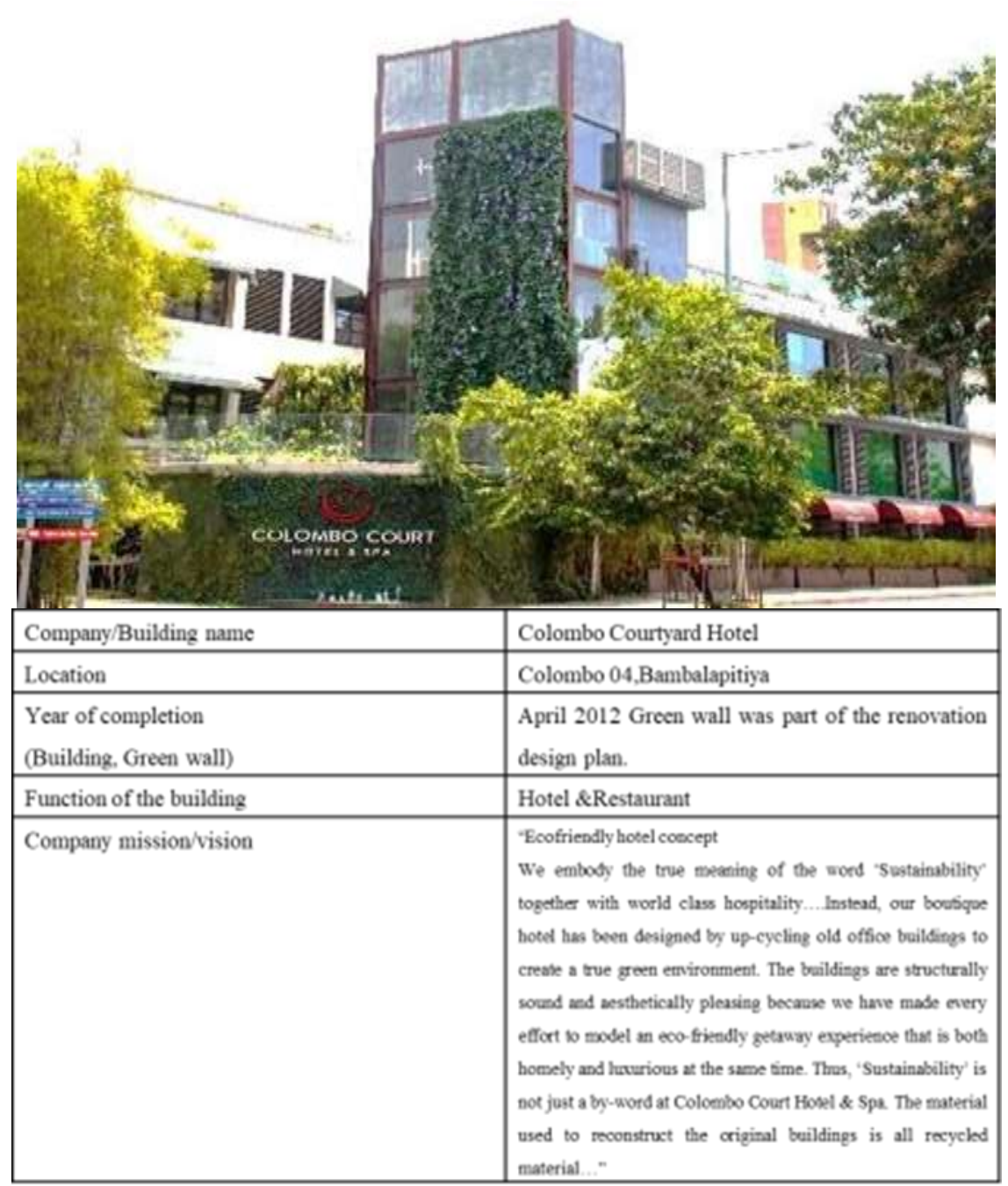




\section{Primary Observation}

\begin{tabular}{|c|c|}
\hline Green wall Type & $\begin{array}{l}\text { Climbing facades -Faced supported green wall } \\
\text { with three dimeasional trellis }\end{array}$ \\
\hline Plant types & $\begin{array}{l}\text { Bengal elockvine } \\
\text { (Thumbersia stradeflonaj- Ay vine } \\
\text { Blue \& white }\end{array}$ \\
\hline $\begin{array}{l}\text { Surface area of the vertical greenery } \\
\text { compared to total beilding facade \& }\end{array}$ & $\begin{array}{l}63 \mathrm{sqm} / 187 \mathrm{spm} \text { (rest of the facade is glass with } \\
\text { Aluminum frames) }\end{array}$ \\
\hline Design strategies & $\begin{array}{l}\text {-used green wall to block the direct sunlight and it } \\
\text { swes the energy required to air condition the glass } \\
\text { cube. } \\
\text {-succensfully achieved long span of climbing } \\
\text { creeper method op to five flooss \& half of the } \\
\text { facade }\end{array}$ \\
\hline Maintenance requirement & $\begin{array}{l}\text { Less mainteance: main trimming and fertilizer } \\
\text { provided once in six mooths. Watering the plant } \\
\text { daily. }\end{array}$ \\
\hline Other observations & $\begin{array}{l}\text { Invects, aats, butterflies \& spider habitats ase } \\
\text { developing. Little binds' nest was observed. As the } \\
\text { plant flowers the facade changes accordingly. }\end{array}$ \\
\hline
\end{tabular}

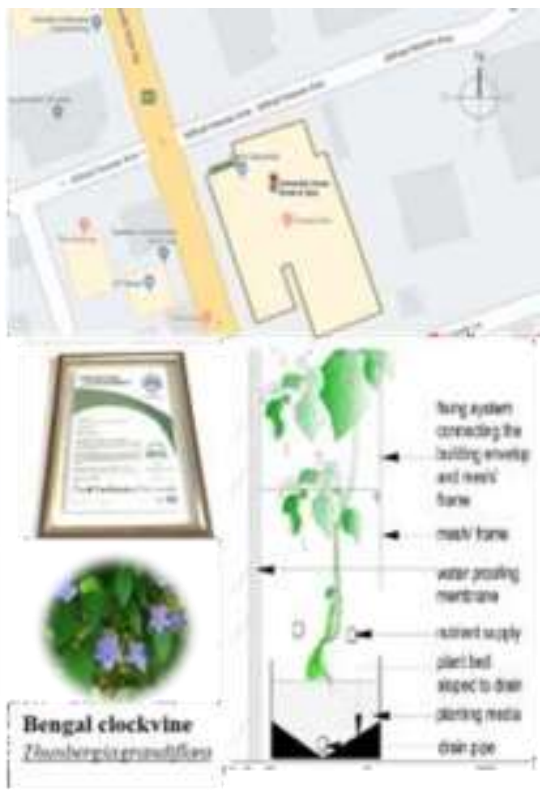

It is by the architect at the clients' request from the initial design stage of the addition to the building. Placed in front of glass façades facing the sun all day, this was introduced to mitigate the heat gain. It wanted fast growing creepers, hence, the plant selection. 


\begin{tabular}{|c|c|c|}
\hline $\begin{array}{l}\text { Panametes bosod ce the } \\
\text { owiroument } \\
\text { sastainability of a getea } \\
\text { wall }\end{array}$ & Factors to coscisker & Reviews Conaneats \\
\hline \multirow[t]{3}{*}{ Respoese to the site } & Orientation & 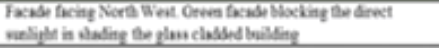 \\
\hline & Soubd/acoustic barrier & 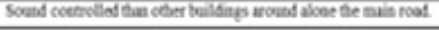 \\
\hline & $\begin{array}{l}\text { Respoase to climate } \\
\text { (Active passive) }\end{array}$ & 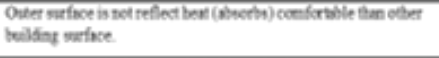 \\
\hline \multirow[t]{3}{*}{ ladoot air quality } & $\begin{array}{l}\text { Carbon dioxide mitipation } \\
\text { and axygen re production }\end{array}$ & 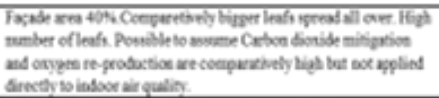 \\
\hline & User Comfout & 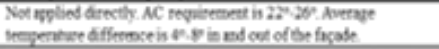 \\
\hline & Dust proof & 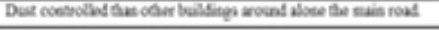 \\
\hline \multirow[t]{2}{*}{$\begin{array}{l}\text { Natural high \& } \\
\text { ventilation }\end{array}$} & $\begin{array}{l}\text { Natural antificial } \\
\text { ventilation }\end{array}$ & 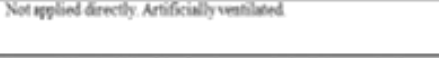 \\
\hline & Natural/artificial lighting & 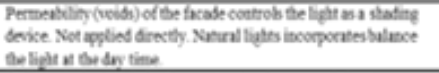 \\
\hline \multirow[t]{3}{*}{ Water \& eatry swing } & $\begin{array}{l}\text { Water supply imgatioa } \\
\text { system }\end{array}$ & 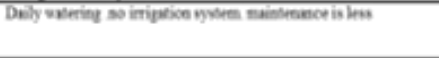 \\
\hline & $\begin{array}{l}\text { Embodied energy of the } \\
\text { structure }\end{array}$ & 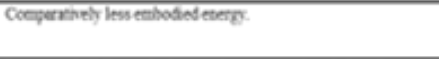 \\
\hline & Maintenance \& cost & 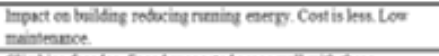 \\
\hline \multirow[t]{3}{*}{ Innovative desien } & Installation method & 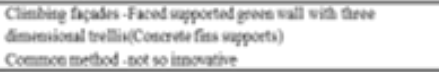 \\
\hline & $\begin{array}{l}\text { Local material/ local } \\
\text { fricadly }\end{array}$ & Notconisend \\
\hline & Possiblities to improve & 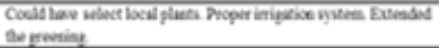 \\
\hline \multirow[t]{3}{*}{ Ecological perception } & $\begin{array}{l}\text { Wild life + ecosystem } \\
\text { response }\end{array}$ & 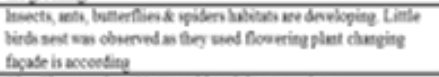 \\
\hline & Respoese to biodiversity & 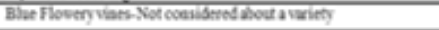 \\
\hline & Endenic plants of aot & Notocenibend \\
\hline \multirow[t]{3}{*}{ Phissological impact } & $\begin{array}{l}\text { Castomer attraction image } \\
\text { building }\end{array}$ & 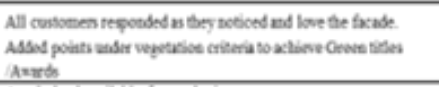 \\
\hline & $\begin{array}{l}\text { land mailability for } \\
\text { gasdening }\end{array}$ & 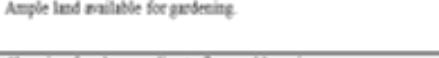 \\
\hline & Aesthetic & 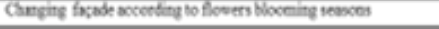 \\
\hline
\end{tabular}
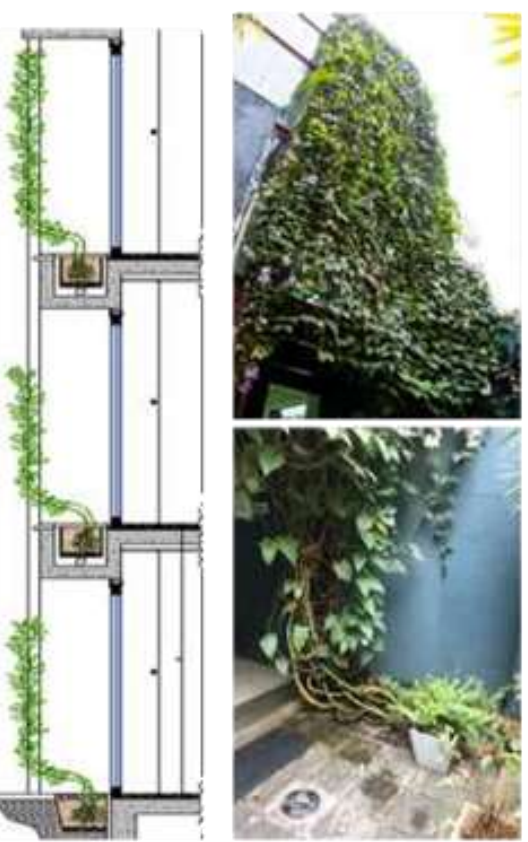

\section{Data Analysis \& Conclusion}

The green facade covers half of the glass facade placed to make the space feel bigger from inside and reduces the heat gain. That makes the building habitable and reduces the power needed for air conditioning; the permeability (voids) of the facade provides enough light. Daily watering is exercised. The green wall is subject to monthly maintenance. Aesthetic goal was achieved by creepers and their flowering changes the facade. The client uses it as a representation of environment sustainability to impress clients. 


\section{Case Study 5 - MAS Innovation Center, Colombo 02}

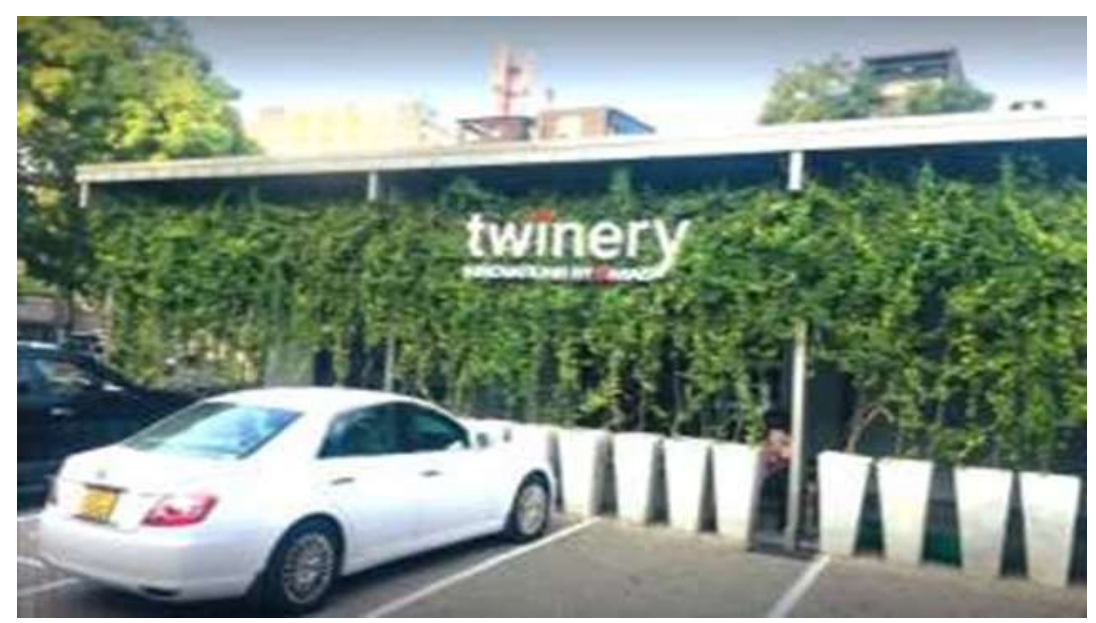

\begin{tabular}{|c|c|}
\hline Company/Building name & $\begin{array}{l}\text { Twinery Innovation by MAS: Smart Clothes \& } \\
\text { Fashion Technologies (Innovation center) }\end{array}$ \\
\hline Location & Union place, Colombo 02 \\
\hline $\begin{array}{l}\text { Year of completion } \\
\text { (Building. Green wall) }\end{array}$ & 2016 ,both building \& green wall \\
\hline Function of the building & Auditorium, Institutional \\
\hline Company mission/vision & 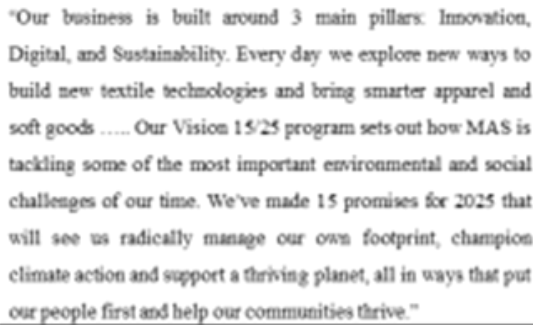 \\
\hline
\end{tabular}




\section{Primary Observation}

\begin{tabular}{|c|c|}
\hline Green wall Type & $\begin{array}{l}\text { Climbing façades -Faced supported green wall } \\
\text { with three dimensional trellis }\end{array}$ \\
\hline Plant types & $\begin{array}{l}\text { (Pentalinonluterum) } \\
\text { hammock viper's-tail, licebush, wild allamanda, }\end{array}$ \\
\hline $\begin{array}{l}\text { Surface area of the vertical greenery } \\
\text { compared to total building façade }\end{array}$ & $54 \mathrm{sqm} / 63 \mathrm{sqm}$ \\
\hline Design strategies & $\begin{array}{l}\text {-There's a corridor in-between the auditorium and } \\
\text { the green wall which acts as an air gap. } \\
\text {-Green wall acts as a shading device for the } \\
\text { corridor. } \\
\text {-Creepers are planted in a series of huge pots in a } \\
\text { row that is featured on the façade. }\end{array}$ \\
\hline Maintenance requirement & $\begin{array}{l}\text { Less maintenance; requirement is once in three } \\
\text { months but they does maintain whole garden } \\
\text { monthly. (According to landscapist). Plants are } \\
\text { watered daily. }\end{array}$ \\
\hline Other observations & $\begin{array}{l}\text { Company has used a flowery plant with } \\
\text { comparatively thick leaves. Insects, bugs, spiders, } \\
\text { lizards, skink, and ants habitat around }\end{array}$ \\
\hline
\end{tabular}

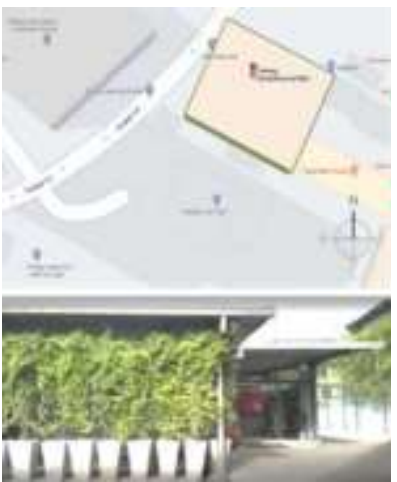

\section{Placement Aspiration \& Method}

This building is located on a small road which connects two main roads. The company's vision is to move towards sustainability in all possible aspects. So greening was a part of client's requirement. Architect used it wisely and in an effective way. The company logo also includes the green façade on its backdrop. This green wall also separates the building from the car park.
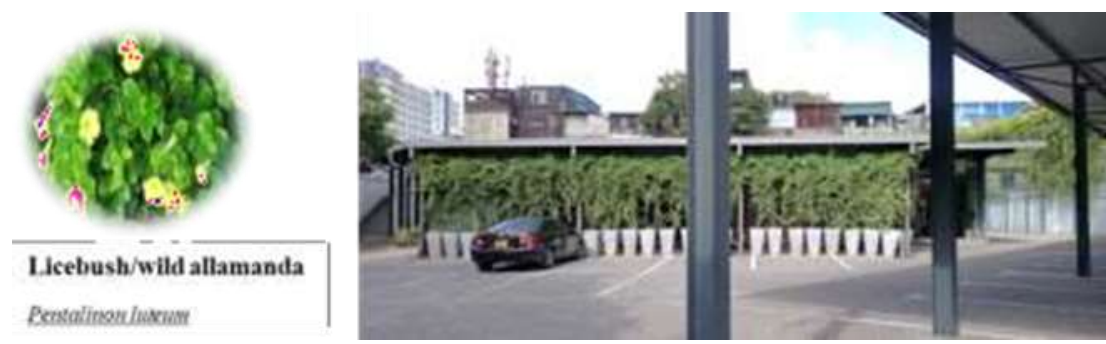


\begin{tabular}{|c|c|c|}
\hline 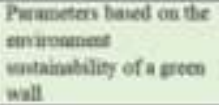 & Facton te coosdar & Kenewcouinath \\
\hline \multirow[t]{3}{*}{ Reyponse to the sine } & Orientatioe & 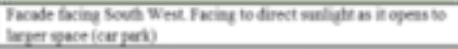 \\
\hline & Sousd acoustic bamief & 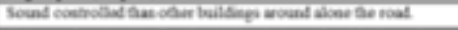 \\
\hline & $\begin{array}{l}\text { Reiponie to climate } \\
\text { (Active passive) }\end{array}$ & 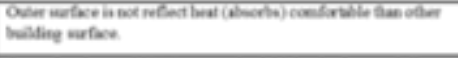 \\
\hline \multirow[t]{3}{*}{ Indoot air qualiny } & $\begin{array}{l}\text { Carbon dioxide mitipation } \\
\text { and exyen re production }\end{array}$ & 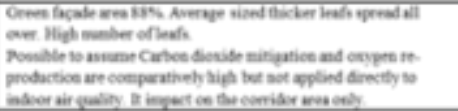 \\
\hline & User Coenfort & 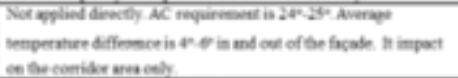 \\
\hline & Dast proof & 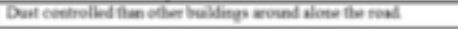 \\
\hline \multirow[t]{2}{*}{$\begin{array}{l}\text { Natural light \& } \\
\text { ventilation }\end{array}$} & $\begin{array}{l}\text { Natural artificial } \\
\text { veatilation }\end{array}$ & 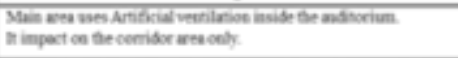 \\
\hline & Natural/ artificial lighting & 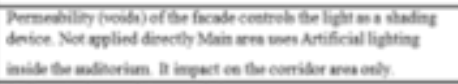 \\
\hline \multirow[t]{3}{*}{ Water \& encrng aving } & $\begin{array}{l}\text { Water supply inrigation } \\
\text { sytem }\end{array}$ & 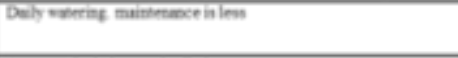 \\
\hline & $\begin{array}{l}\text { Embodied energy of the } \\
\text { structure }\end{array}$ & 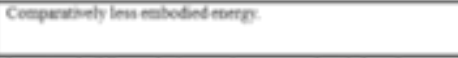 \\
\hline & Maintenasse \& cost & 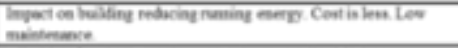 \\
\hline \multirow[t]{3}{*}{ Immovative devign } & Installation method & 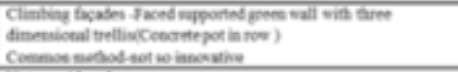 \\
\hline & $\begin{array}{l}\text { Lecal material local } \\
\text { friendly }\end{array}$ & 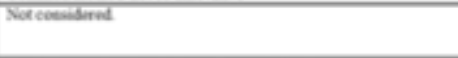 \\
\hline & Posubilities to improve & 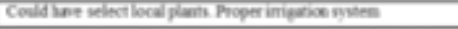 \\
\hline \multirow[t]{3}{*}{ Ecological perceptios } & $\begin{array}{l}\text { Wud life + ecosystem } \\
\text { response }\end{array}$ & 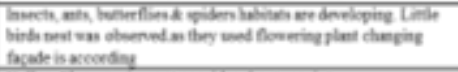 \\
\hline & Plant Tyes-biodiversing & 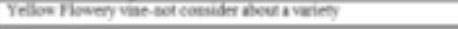 \\
\hline & Exalamix plants of not & 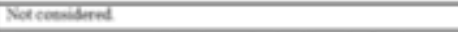 \\
\hline \multirow[t]{3}{*}{ Ptysiological impact } & $\begin{array}{l}\text { Customer aftractioe image } \\
\text { beilleg }\end{array}$ & 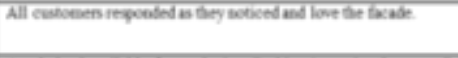 \\
\hline & $\begin{array}{l}\text { lasd avalabtling for } \\
\text { gardening }\end{array}$ & 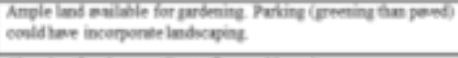 \\
\hline & Aesthetical arpects & 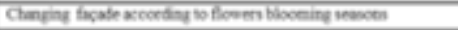 \\
\hline
\end{tabular}

Greening has been included from the initial design of the building. Plant type, shape \& material of the pot were decided in the design phase. During construction, the contractor has applied steel rods to hold and support the façade in the shape the designer wanted

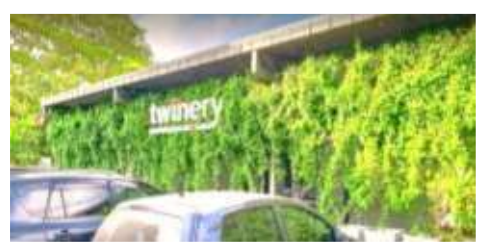

\section{Data Analysis \& Conclusion}

This shades and cools the corridor. According to the staff and the client, it reduced the air condition requirement of the auditorium and reduced the energy bill after the creepers grew fully. The permeability (void) of the creepers removed the need for additional light during the day and naturally ventilated the corridor. Auditorium is not connected to the outside, so, artificially lit and ventilated.

Green walls depend on daily watering twice a day. This foliage doesn't require high maintenance, expect periodic trimming. Tiny creatures inhabit around the green wall. Flowery plant of the green façade changes the facade seasonally. It aesthetically attracts everyone who entered the building. 


\section{Case Study 6 - Residential Project- Colombo 09}

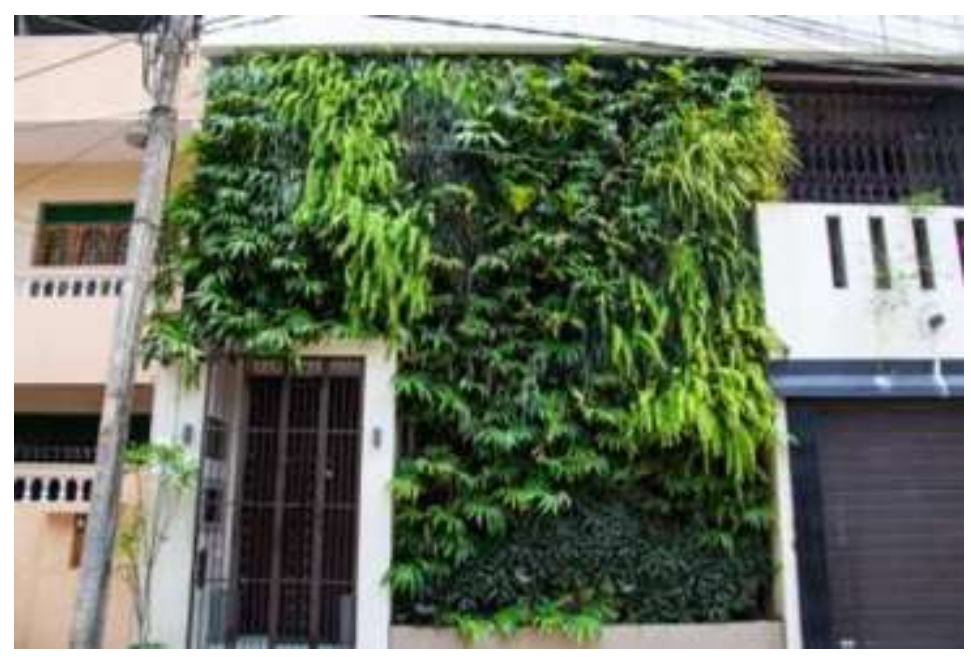

\begin{tabular}{|l|l|}
\hline Compang Building name & Dr. Amila Walawwaththa's bouse \\
\hline Location & Mahavila Garden Dematagoda. Colombo 09 \\
\hline $\begin{array}{l}\text { Year of completion } \\
\text { (Building, Green wall) }\end{array}$ & 2015 \\
\hline Function of the building & Green wall was installed as a later 2016 \\
\hline Company missios/vision & Residential \\
\hline
\end{tabular}

\section{Primary Observation}

\begin{tabular}{|c|c|}
\hline Green wall Type & Kangaroo pouches/Hanging (geo textile) pockets \\
\hline Plant types & $\begin{array}{l}\text { Roheo (Tradescantia spathacea) } \\
\text { (Ophiopogmi Mondo grass } \\
\text { (Drawf mondo grass, Variegated Mondo Grass) } \\
\text { Fernu/Nephinolepis exaltrata)/Sword fern } \\
\end{array}$ \\
\hline $\begin{array}{l}\text { Surface area of the vertical greenery } \\
\text { compared to total building facade }\end{array}$ & $\begin{array}{l}14 \mathrm{sqm} / 42 \mathrm{sqm} \text { (rest of the façade is concrete walls } \\
\& \text { windows (glass with timber frames) }\end{array}$ \\
\hline Design strategies & $\begin{array}{l}\text {-A pattern created by placing a variety of plants. } \\
\text {-easy to upgrade and maintain } \\
\text {-the system itself sustains the water. soil and } \\
\text { fertilizer }\end{array}$ \\
\hline Maintenance requirement & $\begin{array}{l}\text { Once in three months (but the client trim and } \\
\text { upgrades monthly): there is a drip imigation } \\
\text { system to water the plants daily; the geo textile } \\
\text { material sustains water within the system }\end{array}$ \\
\hline Other observations & $\begin{array}{l}\text { Insects, bugs, spiders, lizards, skink, and ants } \\
\text { inhabit around. Pattern achieved via a variety of } \\
\text { plants. }\end{array}$ \\
\hline 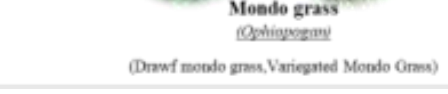 & 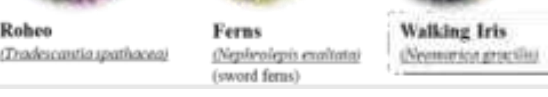 \\
\hline
\end{tabular}

'Cities People Places': an International Journal on Urban Environments Centre for Cities, University of Moratuwa, Sri Lanka 


\section{Placement Aspiration \& Method}

The greening was done according to a request of Mrs. Walawwaththa (Doctor's wife) who is in to gardening but the house was built on the entire plot. Client wanted an environmentally connected entrance to the house. Architect encouraged a roof garden which is functioning well, but the client was not satisfied by not seeing any greenery until they go to roof. So, the client and his wife decided to cover the facade facing the roadway by using a green wall and upgraded the facade. They said even though the initial placement was expensive, the maintenance and upgrading are easier due to the kangaroo pouches method.

\begin{tabular}{|c|c|c|}
\hline $\begin{array}{l}\text { Parameters based on the } \\
\text { eaviroument } \\
\text { sustainability of a groen } \\
\text { wall }\end{array}$ & Factors to constder & Reviews Couments \\
\hline \multirow[t]{3}{*}{ Response to the site } & Oricntation & 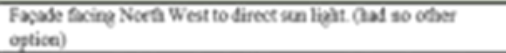 \\
\hline & Sound/Acoustic barrier & 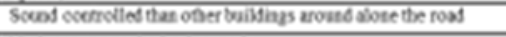 \\
\hline & $\begin{array}{l}\text { Response to climate } \\
\text { (Active passive) }\end{array}$ & 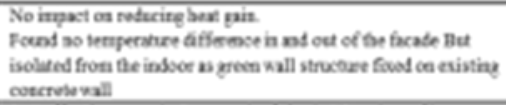 \\
\hline \multirow[t]{3}{*}{ Indoor air quality } & $\begin{array}{l}\text { Carbon diocide } \\
\text { mitigation and oxygen } \\
\text { te produxtion }\end{array}$ & 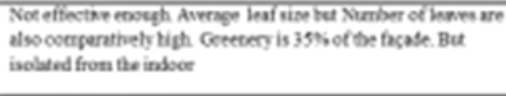 \\
\hline & User Comfort & 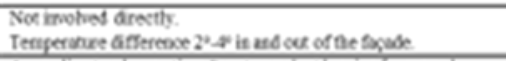 \\
\hline & Dust proof & Aocending to obvervatica, if act as a deat furrier fron rosi \\
\hline \multirow[t]{2}{*}{$\begin{array}{l}\text { Natural lighn } \mathbf{A} \\
\text { ventilatioe }\end{array}$} & $\begin{array}{l}\text { Naruralartificial } \\
\text { ventilation }\end{array}$ & Notinobed droctly \\
\hline & $\begin{array}{l}\text { Nanural artificial } \\
\text { lighting }\end{array}$ & Notinolved diroctly \\
\hline \multirow[t]{3}{*}{ Water $\&$ esergy saving } & $\begin{array}{l}\text { Water supply/migation } \\
\text { system }\end{array}$ & 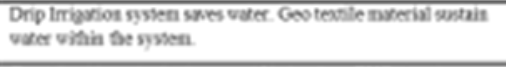 \\
\hline & $\begin{array}{l}\text { Embodied energy of the } \\
\text { structure }\end{array}$ & 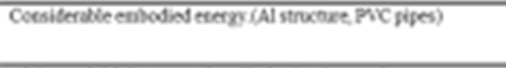 \\
\hline & Maintesunce \& cost & 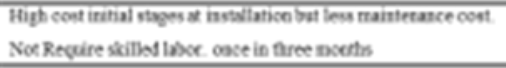 \\
\hline \multirow[t]{3}{*}{ lnnovative design } & Installation method & Knazoo pouber Hanize (Ceo Tentile) poches \\
\hline & $\begin{array}{l}\text { Local material/ocal } \\
\text { friendly }\end{array}$ & Not cotaidarod \\
\hline & Possibilities to improve & 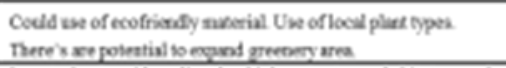 \\
\hline \multirow[t]{3}{*}{ Ecological perception } & $\begin{array}{l}\text { Wild life + ecosystem } \\
\text { respoese }\end{array}$ & 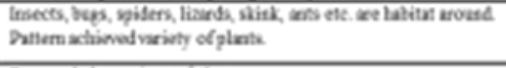 \\
\hline & Respouse to biodiversity & Respobod soveriety of purts. \\
\hline & Endemic plants of not & Not ectaibinud. \\
\hline \multirow[t]{3}{*}{ Physiological impact } & $\begin{array}{l}\text { Customer } \\
\text { aftraction image } \\
\text { building }\end{array}$ & 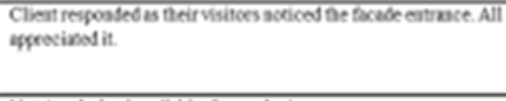 \\
\hline & $\begin{array}{l}\text { land availability for } \\
\text { gardening }\end{array}$ & Nor Anple lase axilbse for girdenity. \\
\hline & Aesthetical aspects & 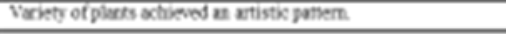 \\
\hline
\end{tabular}

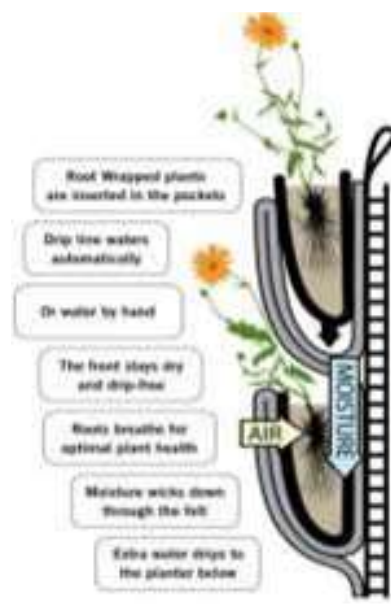

In the construction stage they have gone through several options suggested by the supplier and gone with the option which would stand a long time. Plants were selected during that stage

\section{Data Analysis \& Conclusion}

Orientation of the green wall, facing the road was determined by the available area. The wall acts as a garden, making the entrance pleasing to those who enter and projects calmness to the surrounding. According to the client, sound was reduced after introducing the green wall. It does not change natural light or ventilation of the building as it is solid. The initial cost and embodied energy for this system, Kangaroo pouches are higher than that for climbing creepers. The system contains an aluminum structure and PVC pipe for drip irrigation. The way the geo textile materials are organized helps to sustain water, fertilizer and soil within the system. Upgrading the green wall and replacing plants are easy tasks not requiring skilled labor. 


\section{Summery}

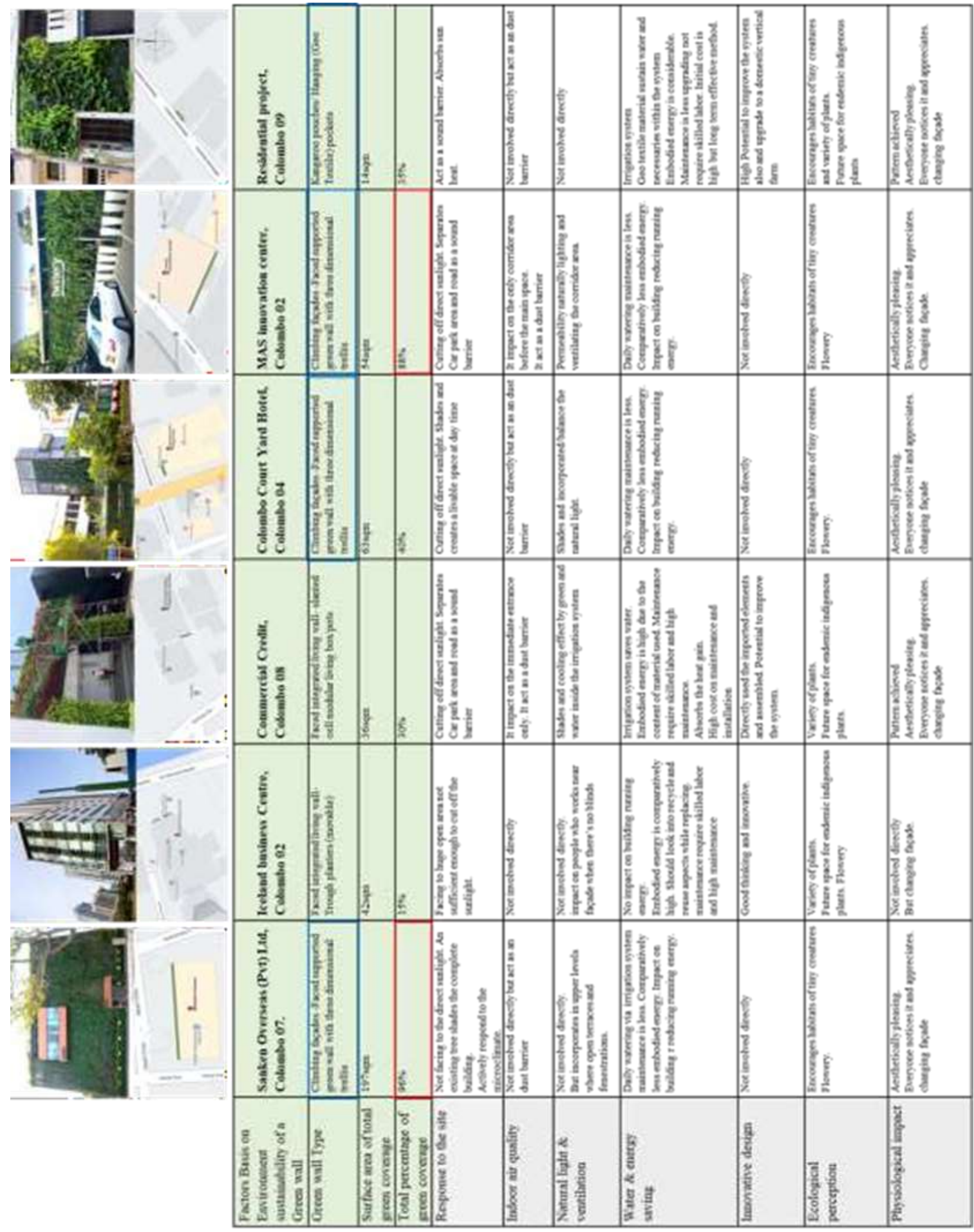


- Above studies show green wall methods used is Colombo are common, inexpensive, low maintenance. "Climbing facades faced supported green wall" is extremely popular.

- These walls are yet to catch up as all designs found in Colombo are rigid. Using a robust design can change based on necessity is recommended.

- The orientation and placement of irrigation systems are problematic, plants and installation methods should be more responsive to Sri Lankan client.

- More issues were observed regarding maintenance equipment.

- It is observed that green walls initiated by client and not architects, which is disappointed

- Above designs explicitly mark its presence in environmental and greenery discourses but they are still identified as greenwash as participation is not enough and attraction does not help the cause

- Green walls commonly used ground plants, air plants, grass types, ferns, and ivies.

- Double skin method is the most successful system to achieve bio-climatic benefits such as heat gain reduction, noise reduction and the therapeutic benefits.

- Kangaroo pouches/hanging (geo textile) pockets and climbing facades support green walls with three-dimensional trellis are easy to develop locally and easily adaptable to Colombo city.

\section{Conclusions \& Recommendations}

Are green walls of Colombo meaningfully green? According to this research, they are not environmentally sustainable as they look.

They have achieved aesthetic aspects and given philological impacts, but other aspects are not fulfilled at a satisfactory level. As most of the buildings are air conditioned and have artificially-lit office spaces, the green walls do not provide natural ventilation, lighting or indoor air quality. Moreover, considering the high population density area, people struggle to find actual cleansing effect from these walls during lock-down periods such as COVID-19. Residents did not find any psychological satisfaction.

In conclusion, reality in Colombo city area is way below the idea promoted by environmentalists. Nonetheless, above examples achieved acceptable standards employing inexpensive methods related to the local conditions. It is significant to identify the strengths and build on them towards an environmentally friendly wall system. The architects and architecture programs need to be sensitized.

- Green walls could have extra benefits by having façades that provide herbs to kitchens and potential sales to public

- Innovations could provide cost-effective solutions instead of using chemicals. Innovating solutions rainwater for drip irrigation system and sensors to detect dryness, would make maintaining cost effective.

- Green walls concept should be promoted to every building regardless of its location

- Proposing to use endemic indigenous or local plants for local green walls; such as orchids, Leucas biflora, Impatiens repens, Pyrrosia heterophylla, Evolvulus nummularius, Pothos scandens, Psychotria sarmentosa,Ficus pumila.Common plantsused in Colombo are Bengal clock vine /sky vines (Thunbergia grandiflora) which are fast growing. The higher density of their big leaves can provide privacy.

- Kangaroo pouches/Hanging (geo textile) pockets are manufactured with eco-friendly material.

- Extra income or tax relief could inspire addition of green walls to any constructions. 
- Having areas that appear like forests could help people psychologically especially during remote work or lock downs.

\section{References}

Barry Chignell,(2013), 8 Benefits Of Plants In The Office, Retrieved on 14 March 2014 from: http://www.ciphr.com/blog/plants-in-the-office/

Bowe, Patrick. (2004), Gardens of the Roman World, Getty, Los Angeles.

Brković, D.M,,Radic, M., and Auer, T., 2019 Green Facades and Living Walls-A Review Establishing the Classification of Construction Types and Mapping the Benefits, Research Gate

Daily Mail (London),(2010), Ivy Can Help to Protect Your Home; Plant Could Prevent Walls Cracking, Say Researchers, Retrieved on 14 March 2014: http://www.highbeam.com/doc/1G1-226436221.html

Dalley, Stephanie, (2013),The Mystery of the Hanging Garden of Babylon: an elusive World Wonder traced, Oxford University Press, United Kingdom.

Dunnett, Nigel, and Kingsbury ,Noël. (2004),Planting Green Roofs and Living Walls,Timber Press, Portland

Fediw.K. The 2015.Manual of interior plantscraping. Portland,Oregon, Timber press.

Green Building Council Sri Lanka, 2015.GREEN SL rating system for built environment

Hart, Sara. (2011), Ecoarchitecture: The Work of Ken Yeang , Wiley, New Jursey.

House of Plants, (2005), Sick Building Syndrome and How Interior Plants can Help Cure It, Retrieved on 14 March 2014: http://www.houseofplants.co.uk/sick_building_syndrom.htm

http://www.doctorshangout.com/profiles/blogs/why-are-hospitals-associated-with-the-colourgreen-and-blue.

K. Perini, M. Ottelé, A.L.A. Fraaij, E.M. Haas, R. Raiteri, (2011), Greening the building envelope, façade greening and living wall systems, SciRes.

Kellert, S. R., 2007. Building for Life: Designing and Understanding the Human-Nature Connection. 2nd ed. Washington: Island Press.

Krishna, Murali , (2013) . Why Are Hospitals Associated With The Colour Green And Blue, Retrieved on 14 March 2014.

Leenhardt, Jacques, and Lambertini ,Anne. (2007),Vertical Gardens, Verba Volant, United Kingdom.

Loh, Susan. (2008). Living Walls - A way to Green the Build Environment, BEDP Environment Design Guide, Australia.

McRae Anderson, A. C. (n.d). Living Greenwalls Vertical Planting Systems, Retrieved on 14 March 2014: http://greenwalls.com/home/about/

Moghadam, D. M., 2015. A Brief Discussion on Human/Nature Relationship. Humanities and Social Science, Issue Accessed 15 December, 2017, p. 90.

Muhammad Shamsuddeen Abdullahi, Halil Zafer Alibaba. Facade Greening: A Way to Attain Sustainable Built Environment. International Journal of Environmental Monitoring and Analysis. Vol. 4, No. 1, 2016, pp. 12-20. doi: 10.11648/j.ijema.20160401.13

Myers,William (2012), Biodesign, Thames and Hudson, United Kingdom.

Oxforddictionaries, (n.d), Retrieved on 14 March 2014 from: http://www.oxforddictionaries.com/definition/english/carbon-footprint

Peck, S.W., Callaghan, C., Bass, B., \& Kuhn, M.E. (1999). Greenbacks from green roofs: forging a new industry in Canada. Research Report, Canadian Mortgage and Housing Corporation (CMHC). Canada, Ottawa.

Petty, Nicholas Allen, 2008, Vertical Is The New Horizon, The University of Georgia, Athens. 
Swaffield, S., 2002. Theory in Landscape Architecture: A Reader (Penn Studies in Landscape Architecture). Philadelphia, Pennsylvania 19104-4011: University Of Pennsylvania press.

Tan, P. Y., Chaing, K., Chan, D., Wong, N.H., Chen, Y., et al. (2009). Vertical Greenery For the Tropics, Centre for Urban Greenery and Ecology (CUGE), Singapore.

The Economist(2011), No easy fix, Retrieved on 14 March 2014 from: http://www.economist.com/node/18200678

Tsarouhas. G., 2014. Green Walls Green roofs, Australia, Victoria.

Urban Development Authority(UDA),(2008), City of Colombo development plan(amendment), Ministry of Urban Development and Sacred Area Development, Sri Lnaka.

Vinnitskaya, Irina (2011), Housing In Progress Landscape Boeri Studio Italy Milan Stefano Boeri Architetti , Retrieved on 14 March 2014 from: http://www.archdaily.com/195866/in-progress-bosco-verticale-boeri-studio/

W. Wanniarachchi, Foliage wall in Temple Trees removed, Daliy Mirror-28th Feb 2015

Wender, P. H., 1998. ATTENTION-DEFICIT HYPERACTIVITY DISORDER IN ADULTS. 1st ed. Salt Lake City, Utah: Elsevier Inc.

Williams, R., 2005. The Historical Roots of Our Ecological Crisis.1st ed. Georgia: University of Georgia Press.

Wood, A., Bahrami,P.\& Safarik,D.(2014) Green Walls in High-Rise Building: An output of the CTBUH Sustainability Working Group. Council on Tall buildings and Urban habitat: Chicago

Zhou, H., 2014. Research on environment art design in city planning. Chemical and Pharmaceutical Research, Issue Accessed 18 December, 2017, pp. 6(7):1824-1829. 